Atmos. Meas. Tech. Discuss., doi:10.5194/amt-2016-224, 2016

Manuscript under review for journal Atmos. Meas. Tech.

Published: 2 September 2016

(c) Author(s) 2016. CC-BY 3.0 License.

(c) (i)

\title{
Retrieval of effective aerosol diameter from satellite observations
}

\author{
Humaid Al Badi ${ }^{1,3}$, John Boland ${ }^{1}$, David Bruce ${ }^{2}$
}

${ }^{1}$ Centre for Industrial and Applied Mathematics and ${ }^{2}$ Natural and Built Environments Research Centre, University of South Australia, Mawson Lakes, 5095, Australia.

${ }^{3}$ Directorate General of Meteorology, Public Authority for Civil Aviation, Oman.

Correspondence to: Humaid Al Badi (h.albadi@gmail.com)

Abstract. Dust aerosol particle size plays a crucial role in determining dust cycle in the atmosphere and the extent of its impact on the other atmospheric parameters. The in-situ measurements of dust particle size are very costly, spatially sparse and time-consuming. This paper presents an algorithm to retrieve effective dust diameter using infrared band brightness temperature from SEVIRI (the Spinning Enhanced Visible and InfaRed Imager) on the Meteosat satellite. An empirical model was constructed that directly relates differences in brightness temperatures of 8.7, 10.8 and $12.0 \mu \mathrm{m}$ bands to dust effective diameter using the Mie extinction efficiency factor. Three case studies are used to test the model. The results showed consistency between the model and in-situ aircraft measurements. A severe dust storm over the Middle-East is presented to demonstrate the use of the model. This algorithm is expected to contribute to filling the gap created by the discrepancies between the current size distributions retrieval techniques and aircraft measurements. Potential applications include enhancing the accuracy of atmospheric modelling and forecasting horizontal visibility and solar energy system performance over regions affected by dust storms.

\section{Introduction}

Aerosols including dust have a significant impact on the climate through a range of complex mechanisms. In the short term, the effects of aerosol variability generate perturbations in atmospheric turbidity. Aerosols alter atmospheric turbidity by modifying the flux of solar short-wave and terrestrial long wave radiation through scattering and absorption (Goudie \& Middleton 2001). The amount of absorption and forward and backward scattering depends on the concentration, size distribution and chemical composition of aerosol particles. Despite continued research, the multiple aerosol effects are still poorly represented in climate models which lead to substantial uncertainty (Ben-Ami et al. 2010; Boucher et al. 2013). One of the reasons for such uncertainty might be the scarcity of adequate and routine measurements of aerosol properties. Most of the particle size in-situ measurements in operation take place on the ground by sampling the precipitated aerosols (Afeti \& Resch 2000; Sunnu, Afeti \& Resch 2008). Ground measurements are not sufficient because aerosols have different and dynamic vertical distribution. Limited aircraft campaigns have been conducted to sample the aerosols particle size in the atmosphere ( e.g. Tanré et al. 2003; Müller et al. 2012; Ryder et al. 2013b; Ryder et al. 2013a). 
Atmos. Meas. Tech. Discuss., doi:10.5194/amt-2016-224, 2016

Manuscript under review for journal Atmos. Meas. Tech.

Published: 2 September 2016

(c) Author(s) 2016. CC-BY 3.0 License.

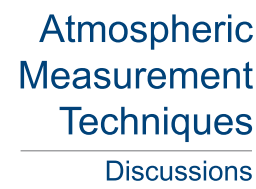

(c) (i)

The sparsity of in-situ dust sampling opened the door for remote sensing techniques to fill the gap.

Nakajima et al. (1996) and Dubovik \& King (2000) developed inversion algorithms for retrieval of the aerosol volume

distribution $\left(\frac{d V}{d \ln r}\right)$ from Sun and sky radiance ground measurements, such as AErosol RObotic NETwork (AERONET).

From space, Atmospheric Infrared Sounder (AIRS) observations made at $9.4 \mu \mathrm{m}$ are used to retrieve dust effective radius

(Pierangelo et al. 2005). Klüser et al. (2011) also used a Singular Vector Decomposition method on observed spectra from the Infrared Atmospheric Sounding Interferometer (IASI) to extract dust effective radius.

However, the current techniques do not satisfy the need for accurate dust particle size data. Discrepancies have been observed in retrieving the size distributions between the AERONET algorithm (Dubovik \& King 2000), the Sky Radiation (SKYRAD) algorithm (Nakajima et al. 1996) and aircraft measurements (Estellés et al. 2012; Ryder et al. 2015). The comparison between in-situ sampling during Saharan Mineral Dust Experiment (SAMUM) 2006 and AERONET effective radii retrieval showed that the Sun photometer observations are smaller by a factor of two compared to the in-situ observations (Müller et al. 2012). The underestimation of the dust size distribution also appears to be a common pattern among the current satellite algorithms (Klüser et al., 2011; Pierangelo et al. 2005). The abundance of large particles over desert surfaces might have a role in reducing the accuracy of the current sunphotometer and satellite techniques (Ryder et al. 2013b). This paper presents a new approach in retrieving effective dust particle size to reduce the gap between the observed dust particle size and the current retrieval methods.

The algorithm uses infrared band brightness temperature from SEVIRI (the Spinning Enhanced Visible and InfaRed Imager) on Meteosat satellite. Infrared window bands 12.0, 10.8 and $8.7 \mu \mathrm{m}$ are widely used to track dust plumes in operational meteorological applications. In 2003 the first METEOSAT Second Generation Satellite was launched carrying SEVIRI. It has an unprecedented temporal resolution of 15-minutes over the Sahara Desert and the West Asia regions where the primary dust sources in the world are located. The Dust Red, Green and Blue (Dust RGB) image composite corresponding to infrared window band combination of 12.0-10.8, 10.8-8.7 and $10.8 \mu \mathrm{m}$ respectively, is one of the most used combinations to track dust clouds (EUMETSAT 2016). The Dust RGB composite uses the fact that the change of the bands brightness Temperature $(T)$ is strongly correlated to the change in the scattering and absorption caused by dust variability in the atmosphere. That is, the dust aerosol variability alters the radiation flux falling on the satellite radiometer from which $T$ is calculated. The correlation between $T$ and dust aerosols is rather complex and linked to many parameters. It is mainly caused by Aerosols Optical Depth(AOD), dust particle size and shape and the emissivity which in turn linked to dust chemical composition (e.g. Brindley et al. 2012; Klüser et al. 2011). The method presented here shows it is possible to reduce this correlation complexity when the brightness temperature difference is used to retrieve effective dust size. An analytical approach of the Mie extinction efficiency factor is used to build an empirical model to link effective dust diameter with brightness temperature difference of 8.7 and $12.0 \mu \mathrm{m}$. 
Atmos. Meas. Tech. Discuss., doi:10.5194/amt-2016-224, 2016

Manuscript under review for journal Atmos. Meas. Tech.

Published: 2 September 2016

(c) Author(s) 2016. CC-BY 3.0 License.

(c) (i)

\section{Atmospheric \\ Measurement \\ Techniques \\ Discussions}

\section{Calculating the Mie scattering efficiency factor for dust}

To assess how much a spherical dust particle scatters light, the extinction efficiency factor $Q_{\text {ext }}$ needs to be introduced. Any particle of diameter $d$ which blocks the radiation path will remove power from the incident radiation with intensity $I_{0}$ by an amount $P_{\text {removed }}$

$$
P_{\text {removed }}=C_{\text {ext }} I_{0}
$$

where $C_{\text {ext }}$ is the extinction cross section (Hahn 2009).

Mie's solution for Maxwell's electromagnetism equations results in:

$$
C_{\text {ext }}=\frac{\lambda^{2}}{2 \pi} \sum_{n=1}^{\infty}(2 n+1) \operatorname{Re}\left\{a_{n}\left(x, m, \Psi_{n}, \xi_{n}\right)+b_{n}\left(x, m, \Psi_{n}, \xi_{n}\right)\right\}
$$

where $x=\frac{\pi d}{\lambda}$ and it is called the size parameter, $m$ is the refractive index, $a_{n}\left(x, m, \Psi_{n}, \xi_{n}\right)$ and $b_{n}\left(x, m, \Psi_{n}, \xi_{n}\right)$ are Mie scattering coefficients derived from solving Maxwell's equations, and $\Psi$ and $\xi$ are the Ricatti-Bessel functions (Hahn 2009). The extinction efficiency factor $Q_{\text {ext }}$ is commonly used to relate the extinction cross section $C_{\text {ext }}$ to the geometrical cross section $C_{g e o}$ :

$$
Q_{e x t}=\frac{C_{e x t}}{C_{g e o}}
$$

For a sphere $C_{g e o}=\frac{\pi d^{2}}{4}$, Thus:

$$
Q_{\text {ext }}=\frac{2}{x^{2}} \sum_{n=1}^{\infty}(2 n+1) \operatorname{Re}\left\{a_{n}\left(x, m, \Psi_{n}, \xi_{n}\right)+b_{n}\left(x, m, \Psi_{n}, \xi_{n}\right)\right\}
$$

This equation is solved numerically for any given $x$ and $m$ (Hahn 2009).

The refractive index is wavelength and chemical composition dependent. In this paper, the Di Biagio et al. (2014) estimation of the refractive index $m$ has been used where, $m_{8.7}=1.10+0.20 \mathrm{i}, m_{10.8}=1.9+0.25 \mathrm{i}, m_{12.0}=1.75+0.40 \mathrm{i}$ are the values given for the 8.7, 10.8 and $12.0 \mu \mathrm{m}$ refractive index respectively. These refractive index estimations were made in the laboratory for five dust samples collected during dust events originated from different Western Saharan and Sahelian areas (Di Biagio et al. 2014). Figure 1 shows the calculated Mie extinction efficiency factor $Q_{\text {ext }}$ for particle diameter from 1 to 50 $\mu \mathrm{m}$ using MiePlot software (Laven 2016). Berg et al. (2011) provide an explanation why $C_{\text {ext }} \rightarrow 2 C_{g e o}$ and $Q_{\text {ext }} \rightarrow 2$ when the particle diameter becomes very large. 
Atmos. Meas. Tech. Discuss., doi:10.5194/amt-2016-224, 2016

Manuscript under review for journal Atmos. Meas. Tech.

Published: 2 September 2016

(c) Author(s) 2016. CC-BY 3.0 License.

\section{Atmospheric \\ Measurement \\ Techniques \\ Discussions}

\section{Deriving the model}

As Figure 1 shows, Mie theory predicts a significant change in the extinction efficiency factor of the thermal infrared 12.0, 10.8 and $8.7 \mu \mathrm{m}$ when the particle diameter lies between 1 and $20 \mu \mathrm{m}$. This dust range covers the reported effective dust particle size range during the Fennec 2011 aircraft dust sampling campaign over West Africa which was between 2.3 to 19.4 $\mu \mathrm{m}$ for some dust events (Ryder et al. 2013b).

Since $C_{\text {ext }}=\frac{P_{\text {removed }}}{I_{0}}$ then $Q_{\text {ext }} \alpha \frac{1}{I_{0}}$. But $T \alpha I_{0}$; thus $Q_{\text {ext }} \alpha \frac{1}{T}$. This implies that the peaks of $Q_{\text {ext }}$ correspond to troughs in brightness Temperature $(T)$. Thus, a small change in effective dimeter $d$ in the range 2.3 to $19.4 \mu \mathrm{m}$ will result in a significant change in brightness temperature. The pattern of 8.7 and $12.0 \mu \mathrm{m}$ curves in Figure 1 also suggests that the difference $T_{8.7-12.0}$ versus effective diameter $d$ will have the same curve shape as properly scaled Ryleigh distribution function. The Ryleigh distribution has the generalised formula:

$f(x)=\frac{x}{\alpha^{2}} e^{-\frac{x^{2}}{\alpha^{2}}} \quad($ Walck 2007)

Thus

$T_{8.7-12.0} \alpha a^{\prime} \frac{d}{b^{\prime 2}} e^{-\frac{d^{2}}{b^{\prime 2}}}$ where $a^{\prime}, b^{\prime}, c^{\prime}$ are scaling coefficients

The theoretical curves of extinction coefficient in Figure 1 assumes the same amount of energy emitted from the ground towards space. In reality, there is a significant difference in the ground emissivity between the three bands; 12.0, 10.8 and $8.7 \mu \mathrm{m}$. In this paper, the Global Infrared Land Surface Emissivity Database has been used (Seemann et al. 2008). As Figures $2 \& 3$ show, the band $8.7 \mu \mathrm{m}$ has the strongest variation in emissivity while $12.0 \mu \mathrm{m}$ is homogenous around a relatively high value of 0.93 over desert surfaces. Assuming $12.0 \mu \mathrm{m}$ emissivity is constant, as $8.7 \mu \mathrm{m}$ emissivity $\left(\in_{8.7}\right)$ increases, the difference $T_{8.7-12.0}$ also increases. Additional impact of emissivity difference originates from the dust layer. Furthermore, as the dust diameter increases the contribution of the dust layer emissivity increases (Takashima \& Masuda 1987). In summary, it is safe to say;

$$
T_{8.7-12.0} \alpha \in_{8.7}^{2} d
$$

which leads to:

$$
\frac{T_{8.7-12.0}}{\epsilon_{8.7}^{2}}=a \frac{d^{2}}{b^{2}} e^{-\frac{d^{2}}{b^{2}}}+c d+f
$$

where $\epsilon_{8.7}$ is the ground emissivity at $8.7 \mu \mathrm{m} ; a, b, c$ and $f$ are constants.

(Figures $2 \& 3$ here)

Actual values of $\left(\frac{T_{8.7-12.0}}{\epsilon_{8.7}^{2}}, d\right)$ from two dust events were used to calculate the coefficients $a, b, c$ and $f$ numerically. The first one is a dust case sampled by Fennec b604, 20 June 2011 (Ryder et al. 2013b). The reported mean $d$ was around $6 \mu \mathrm{m}$ and the emissivity $\epsilon_{8.7}$ at the location (Figure 4) is 0.72 . Figure 5 shows the brightness temperature change of 8.7, 10.8 and $12.0 \mu \mathrm{m}$ bands versus time of the $20^{\text {th }}$ of June 2011 at the experiment location $(24.0 \mathrm{~N}, 10.0 \mathrm{~W})$. The second dust event was a 
Atmos. Meas. Tech. Discuss., doi:10.5194/amt-2016-224, 2016

Manuscript under review for journal Atmos. Meas. Tech.

Published: 2 September 2016

(c) Author(s) 2016. CC-BY 3.0 License.

(c) (i)

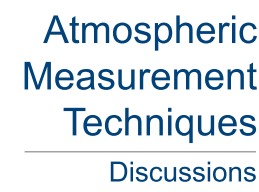

severe dust storm which is utilized to guide the model at high $d$ values. Figure 6 shows the brightness temperature of a severe dust case over West Asia at location 27.0N, 47.8E (detailed description is in Section 5). In this case, few points of $\left(\frac{T_{8.7-12.0}}{\epsilon_{8.7}^{2}}, d\right)$ could be estimated from the small pocket of $T_{12.0-10.8}$ negative values formed around $15 \mu \mathrm{m}$ diameter when $\mathrm{T}_{8.7}-\mathrm{T}_{12.0}>0$. That occurs when $10.8 \mu \mathrm{m}$ band extinction factor is less than $12.0 \mu \mathrm{m}$ band extinction factor which is around $15 \mu \mathrm{m}$ in Figure 1 .

(Figures $4,5 \& 6$ here)

The numerical solution results in coefficients: $a=29, b=12.5, c=1$ and $f=-29.2$. Figure 7 shows a plot of the model $\frac{T_{8.7-12.0}}{\epsilon_{8.7}^{2}}$ versus the effective diameter $d$ in the range $[1,25] \mu \mathrm{m}$ with the actual points used to calculate the coefficients $a, b, c$ and $f$. For convince, a Look Up Table (LUT) was created for given $d$ and the corresponding $\frac{T_{8.7-12.0}}{\epsilon_{8.7}^{2}}$ values. (Figure 7 here)

Although the extinction efficiency in Figure 1 implies that $\mathrm{T}_{12.0}$ should be greater than $\mathrm{T}_{10.8}$; in a low dust concentration atmosphere $\mathrm{T}_{12.0}<\mathrm{T}_{10.8}$. Figure 8 shows a diurnal change of $\mathrm{T}_{12.0}$ compared to $\mathrm{T}_{10.8}$ during a relatively low dust concentration event. The slight cooling in the $12.0 \mu \mathrm{m}$ band is explained by higher water vapour absorption in the lower part of the atmosphere (EUMETSAT 2016). With increasing dust particle concentration, most of the radiation falling on the satellite sensor will be coming from scattered or reemitted light at the dust layer level. In this case, where the emissivity from dust layer is dominating, the brightness temperature curves of the three bands are expected to be guided by the dust extinction efficiency in Figure 1. On the other hand, when dust concentration is low, it is not expected the model to give accurate results because of the shift caused by the water vapour cooling of $\mathrm{T}_{12.0}$. Thus, in this study, the clear sky is defined as an atmosphere when $\mathrm{T}_{12.0}-\mathrm{T}_{10.8}<0$ and $\mathrm{T}_{8.7}-\mathrm{T}_{12.0}<0$.

(Figure 8 here)

Aerosol Optical Depth (AOD) has a strong correlation with the absolute brightness temperature; however, what is used in the model is brightness temperature difference. A plot of the comparison between $T_{8.7}-T_{12.0}$ and AOD suggests a limited correlation. It appears that the difference filters the strong correlation between AOD and the absolute brightness temperature. Figure 9 shows an example of AERONET AOD and SEVIRI $\mathrm{T}_{8.7}-\mathrm{T}_{12.0}$ for six days over the city of Abu Dhabi which witnessed two successive dust events in that period. Dust RGB animation revealed that the first peak of AOD corresponds to relatively fresh transported dust with large dust effective size, while the second peak corresponds to mainly long transported dust with smaller dust size that is expected to denominate the $\mathrm{T}_{8.7}-\mathrm{T}_{12.0}$ curve. The different behaviour of $\mathrm{T}_{8.7}-\mathrm{T}_{12.0}$ curve around the two AOD peaks clearly indicates different causes, which can be explained by different effective dust diameters. 
Atmos. Meas. Tech. Discuss., doi:10.5194/amt-2016-224, 2016

Manuscript under review for journal Atmos. Meas. Tech.

Published: 2 September 2016

(c) Author(s) 2016. CC-BY 3.0 License.

(c) (i)

$\begin{array}{r}\text { Atmospheric } \\ \text { Measurement } \\ \text { Techniques } \\ \hline \text { Discussions }\end{array}$

\section{Testing the algorithm}

Three cases over West Africa (Figure 10) are presented here to test the algorithm. The sampling in the three cases was carried out by Fennec aircraft campaign during June 2011 over West Africa (Ryder et al. 2013b). In all cases, the location of brightness temperature curves was chosen to be as close as possible to the middle of the sampling area and where there was minimum cloud presence at the time of sampling. The time slots with cloud contamination have been removed.

(Figure 10 here)

\subsection{Case 1: Mali; 17-18 June 2011:}

The dust was sampled by Fennec flight number b600, 17 June 2011 10:00 to 11:15 UTC during the emission phase of the dust event (Ryder et al. 2013b). There was another sampling mission (Fennec 601) on the same day between 17:15 to 18:15 UTC. The reported mean $d$ from Fennec sampling was around $12.3 \mu \mathrm{m}$. Figure 11 shows the calculated $d$ using the model and the BT of $8.7,10.8$ and $12.0 \mu \mathrm{m}$ bands versus time at $21.2 \mathrm{~N}, 5.6 \mathrm{~W}$. The $8.7 \mu \mathrm{m}$ ground emissivity in the location is 0.712 using the Global Infrared Land Surface Emissivity Database (Seemann et al. 2008). There was enough dust concentration for this method to be used starting from 12:00 UTC. The average $d$ from 12:00 to 18:00 UTC was found to be $9.6 \mu \mathrm{m}$. This value is expected to be less than the one reported by Fennec sampling for a "recent uplift" dust event. In the recent uplift stage, incoherent structure of the dust cloud is at maximum, where large particles of dust are present in lower levels and fine dust in the higher level. Another good reason that might contribute to the underestimation is the Fennec aircraft sampling method. The sampling was limited to altitudes beneath $2400 \mathrm{~m}$ above the ground level while SEVIRI measures the radiation coming from the upper part of the dust cloud which might have smaller dust size at higher altitudes.

(Figure 11 here)

\subsection{Case 2: Mauritania; 25 June 2011:}

The second case is another "recent uplift" dust emission. The case was sampled by Fennec b610, 25 June 2011 09:15 to 10:45 UTC (Ryder et al. 2013b). The sampled mean $d$ was around $8.6 \mu \mathrm{m}$. Figure 12 shows the calculated $d$ and the BT of $8.7,10.8,12.0 \mu \mathrm{m}$ bands versus time of the $25^{\text {th }}$ of June 2011 at the location $(25.8 \mathrm{~N}, 7.4 \mathrm{~W})$. Emissivity of $8.7 \mu \mathrm{m}$ band at the location is 0.712 . The average $d$ between 0800 to $1130 \mathrm{UTC}$ is calculated to be $6.2 \mu \mathrm{m}$ which is again expected given the low level sampling which probably selected larger particles due to inhomogeneous fresh dust cloud as in Case 1.

\section{(Figure 12 here)}

\subsection{Case 3: Mauritania; 24-26 June 2011:}

This case is a case of long transported dust and covers a relatively large area which was sampled by four Fennec flights missions over three days (Ryder et al. 2013b). The emissivity of $8.7 \mu \mathrm{m}$ band at the location is 0.732 . Figure 13 shows the calculated $d$ and the brightness temperature of $8.7,10.8,12.0 \mu \mathrm{m}$ bands versus time of the $25^{\text {th }}$ to $26^{\text {th }}$ of June 2011 roughly 
Atmos. Meas. Tech. Discuss., doi:10.5194/amt-2016-224, 2016

Manuscript under review for journal Atmos. Meas. Tech.

Published: 2 September 2016

(c) Author(s) 2016. CC-BY 3.0 License.

(c) (i)

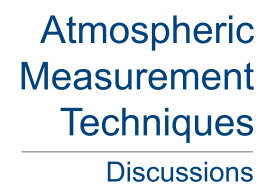

in the centre of the sampling area $(23.7 \mathrm{~N}, 10.3 \mathrm{~W})$. In this case the sampled and retrieved effective diameter $d$ showed very good agreement. The average sampled $d$ for the three days around the flight hours was $5.9 \mu \mathrm{m}$ while the model retrieval shows $d$ of $6.0 \mu \mathrm{m}$.

(Figure 13 here)

Table 1 provides a summary of the testing results. Despite underestimation in recent uplift cases, overall, the model gave promising results. In cases 2 and 3 the sampled value was within 95\% confidence interval for a single value and in case 1 it was just outside this interval.

(Table 1 is here)

\section{Use of the algorithm}

Potential applications for the model include:

a. Verification of atmospheric aerosols models. This application is crucial because of the scarcity of airborne aerosol in-situ measurements.

b. Horizontal visibility forecasting. A sudden drop in horizontal visibility during dust storms is known to be the most direct and hazardous effect of dust storms. Since horizontal visibility is particle diameter dependent, combining particle diameter data from this model with the carrying air mass trajectory forecast from atmospheric models can give an indication of the horizontal visibility from a few hours to a couple of days depending on the location of the emission source.

c. Solar energy system performance forecasting. The performance of the solar power systems depends on the turbidity of the atmosphere which has a correlation with the effective particle diameter. The technique can give an indication of the amount of dust that will precipitate on solar energy systems from an upcoming dust event.

d. Assist in studying the transport behaviours of dust and volcanic ash in the atmosphere.

A severe dust storm is presented here as an example of the model use. The aim is to check model behaviour in severe cases and how dust particle size will change over an extended period. The dust storm originated on $1^{\text {st }}$ of April 2015 over the Arabian Peninsula and affected a large area of western Asia. The brightness Temperature $T$ of the three SEVIRI bands and effective diameter retrieval $d$ was plotted against time around the dust cloud passage for three locations along the track of the dust cloud movement.

Location \# 1 was chosen to be close to the emission source and downstream of wind flow to pick the maximum concentration of emitted dust. The location is at around $300 \mathrm{~km}$ southeast the centre of the emission source (Figure 14).

(Figure 14 here)

(Figure 15 here)

The average background aerosol effective diameter in the early hours of $3^{\text {rd }}$ of April is calculated to be $6.7 \mu \mathrm{m}$ which is not far from the reported background dust of 7.2 by Fennec aircraft campaign during June 2011 (Ryder et al. 2013a). The slight difference can be explained by the heat low pressure, that develops during summer over the desert and helps to keep larger 
Atmos. Meas. Tech. Discuss., doi:10.5194/amt-2016-224, 2016

Manuscript under review for journal Atmos. Meas. Tech.

Published: 2 September 2016

(c) Author(s) 2016. CC-BY 3.0 License.

(c) (i)

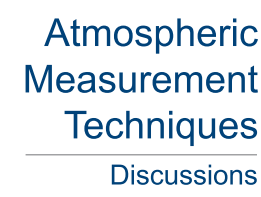

dust particles longer in the air through dry convection. The maximum $d$ in this case was around $14.0 \mu \mathrm{m}$ (Figure 15) which is within the range of the reported $d$ by Fennec aircraft campaign (2.3 -19.4 $\mu \mathrm{m})$.

The effective diameter $d$ can be represented in a 2D map. Figure 16 shows an example for 1st April 2015 18:15 UTC. Most of the clouds were screened out; however, a few water clouds still manifest themselves in this product (e.g. Southeast coast of Yemen). The use of a sophisticated cloud screening algorithm could improve this aspect of the results.

(Figure 16 here)

Location \#2 is the city of Abu Dhabi (Figure 17) and correspond to 24 hours later than Figure 14. Figure 18 shows that the maximum calculated $d$ has dropped to $12.3 \mu \mathrm{m}$ from $14.0 \mu \mathrm{m}$ at Location\#1 24-hour prior. This drop coincides with the fact that $d$ in a dust cloud is inversely proportional with time, because as time progresses large dust particles are precipitated leaving smaller particles in suspension.

(Figure 17 here)

(Figure 18 here)

Location \#3 is chosen to envisage the evolution of the effective diameter of long transported dust after three days from emission (Figure 19 and Figure 20). Xu et al. (2010) found that the volume average diameter of dust particles coming from the sources in western Asia ranged between 3.2 to $4.2 \mu \mathrm{m}$ over the central Himalaya. For Location\#3 in the research reported here and following several cloud animations, on average, the air mass carrying the dust needs around 5.5 days to move from a source over the centre of the Arabian Peninsula and to the central Himalaya. The calculated three-hour average of $d$ after three days was $10.1 \mu \mathrm{m}$ between 06 to 08 UTC on the $4^{\text {th }}$ April. Although central Himalaya is outside SEVIRI coverage, there are still 2.5 days to $d$ to reduce to the average diameter presented by Xu et al. (2010).

(Figure 19 here)

(Figure 20 here)

\section{Potential future improvement in the model}

The accuracy of the numerical solution for the coefficients $a, b, c$ and $f$ in the model can be improved if more in-situ data were used in the calculation. This is important to dilute the bias made by individual in-situ measurements. An example of the bias that could be avoided is the one resulting from constraining the sampling to altitudes lower than 2400 meters, with most samples acquired in a lower part of this air mass (Ryder et al. 2013b). The sampling will be more representative of the column average - from the satellite perspective- if it is extended to higher levels and if sampling time were more evenly distributed vertically. There is also lack of intense dust storms in the published sampled data, with most aircraft sampling being undertaken during relatively low to moderate dust emission events. This is probably for safety reasons, but it does limit the validation of the method for major dust events with larger particle sizes. It will be interesting to observe the use of emerging drone technology to sample dust in intense to severe dust storms. Such data should help to clarify many aspects of dust storms dynamics in general and, fine-tune this model in particular. 
Atmos. Meas. Tech. Discuss., doi:10.5194/amt-2016-224, 2016

Manuscript under review for journal Atmos. Meas. Tech.

Published: 2 September 2016

(c) Author(s) 2016. CC-BY 3.0 License.

(c) (i)

\section{Atmospheric \\ Measurement \\ Techniques \\ Discussions}

Future work will include testing the model with another satellite radiometer outside SEVIRI coverage area. One candidate is the new Advanced Himawari Imager (AHI) on board the Himawari-8 satellite. This instrument provides data that potentially can be exploited to retrieve effective diameter for dust clouds over Australia and central/east Asia. Another interesting feature in Himawari-8 AHI is its extra spectral band in the thermal infrared range. In principle, with more spectral bands, the accuracy of retrieval should increase especially in respect to the larger dust size.

\section{Conclusions}

Dust cycle is an important part of the earth system. The current in-situ sampling data of dust particle size are sparse and expensive. Thus, remote sensing retrieval methods have an important role in covering the gap. In this paper, an empirical algorithm has been presented to estimate effective aerosol diameter $d$ using satellite-based observations. The infrared brightness temperature of SEVIRI bands 8.7, 10.8 and $12.0 \mu \mathrm{m}$ were used. The algorithm showed promising consistency with the other means of estimating $d$ in the literature (Table 1). The accuracy of estimating the coefficients in the empirical model is expected to improve if more in-situ $d$ measurements are used in the numerical solution. The foreseen applications include verification of atmospheric aerosols models. Furthermore, the model can assist in predicting atmospheric turbidity when used with air-mass trajectory forecasting and hence predicting of solar energy performance in regions with high dust storm prevalence. 
Atmos. Meas. Tech. Discuss., doi:10.5194/amt-2016-224, 2016

Manuscript under review for journal Atmos. Meas. Tech.

Published: 2 September 2016

(c) Author(s) 2016. CC-BY 3.0 License.

(c) (i)

$\begin{array}{r}\text { Atmospheric } \\ \text { Measurement } \\ \text { Techniques } \\ \hline \text { Discussions }\end{array}$

\section{References:}

Afeti, GM \& Resch, FJ 2000, 'Physical characteristics of Saharan dust near the Gulf of Guinea', Atmospheric Environment, vol. 34 , no. 8 , pp. 1273-1279.

Ben-Ami, Y, Koren, I, Rudich, Y, Artaxo, P, Martin, ST \& Andreae, MO 2010, 'Transport of North African dust from the

Bodélé depression to the Amazon Basin: a case study', Journal Article, Atmospheric Chemistry and Physics, vol. 10, no. 16, pp. 7533-7544.

Berg, MJ, Sorensen, CM \& Chakrabarti, A 2011, ‘A new explanation of the extinction paradox', JOUR, Journal of quantitative spectroscopy and radiative transfer, vol. 112, Elsevier, no. 7, pp. 1170-1181.

Di Biagio, C, Boucher, H, Caquineau, S, Chevaillier, S, Cuesta, J \& Formenti, P 2014, 'Variability of the infrared complex refractive index of African mineral dust: experimental estimation and implications for radiative transfer and satellite remote sensing', Atmospheric Chemistry and Physics, vol. 14, Copernicus GmbH, no. 20, pp. 11093-11116.

Boucher, O, Randall, D, Artaxo, P, Bretherton, C, Feingold, G, Forster, P, Kerminen, V-MV-M, Kondo, Y, Liao, H, Lohmann, U, Rasch, P, Satheesh, SK, Sherwood, S, Stevens, B, Zhang, XY \& Zhan, XY 2013, 'Clouds and Aerosols: Climate Change 2013: The Physical Science Basis Contribution of Working Group I to the Fifth Assessment Report of the Intergovernmental Panel on Climate Change', pp. 571-657.

Brindley, H, Knippertz, P, Ryder, C \& Ashpole, I 2012, 'A critical evaluation of the ability of the Spinning Enhanced Visible and Infrared Imager (SEVIRI) thermal infrared red-green-blue rendering to identify dust events: Theoretical analysis', Journal of Geophysical Research: Atmospheres, vol. 117, no. D7, p. n/a-n/a.

Dubovik, O \& King, MD 2000, 'A flexible inversion algorithm for retrieval of aerosol optical properties from Sun and sky radiance measurements', Journal of Geophysical Research: Atmospheres, vol. 105, no. D16, pp. 20673-20696.

Estellés, V, Campanelli, M, Utrillas, MP, Expósito, F \& Martínez-Lozano, JA 2012, 'Comparison of AERONET and SKYRAD4.2 inversion products retrieved from a Cimel CE318 sunphotometer', Atmospheric Measurement Techniques, vol. 5, Copernicus GmbH, no. 3, pp. 569-579.

EUMETSAT 2016, MSG Interpretation Guide, viewed 1 January 2016,

<http://www.eumetsat.int/website/home/Data/Training/TrainingLibrary/DAT_2044069.html?lang=EN>.

Goudie, AS \& Middleton, NJ 2001, 'Saharan dust storms nature and consequences', Journal Article, Earth-Science Reviews, vol. 56, no. 1, pp. 179-204.

Hahn, DW. 2009, Light Scattering Theory, Department of Mechanical and Aerospace Engineering University of Florida. Klüser, L, Martynenko, D \& Holzer-Popp, T 2011, 'Thermal infrared remote sensing of mineral dust over land and ocean: a spectral SVD based retrieval approach for IASI', Atmospheric Measurement Techniques, vol. 4, Copernicus GmbH, no. 5, pp. 757-773.

Laven, P 2016, MiePlot, viewed 1 January 2016, <http://www.philiplaven.com/mieplot.htm>.

Müller, D, Lee, K-H, Gasteiger, J, Tesche, M, Weinzierl, B, Kandler, K, Müller, T, Toledano, C, Otto, S, Althausen, D \& Ansmann, A 2012, 'Comparison of optical and microphysical properties of pure Saharan mineral dust observed with 
Atmos. Meas. Tech. Discuss., doi:10.5194/amt-2016-224, 2016

Manuscript under review for journal Atmos. Meas. Tech.

Published: 2 September 2016

(c) Author(s) 2016. CC-BY 3.0 License.
Atmospheric

Measurement

Techniques

Discussions

AERONET Sun photometer, Raman lidar, and in situ instruments during SAMUM 2006', Journal of Geophysical Research: Atmospheres, vol. 117, no. D7, p. n/a-n/a.

Nakajima, T, Tonna, G, Rao, R, Boi, P, Kaufman, Y \& Holben, B 1996, 'Use of sky brightness measurements from ground for remote sensing of particulate polydispersions', Applied Optics, vol. 35, Optical Society of America, no. 15, p. 2672.

Pierangelo, C, Mishchenko, M, Balkanski, Y \& Chédin, A 2005, 'Retrieving the effective radius of Saharan dust coarse mode from AIRS', Geophysical Research Letters, vol. 32, no. 20, p. L20813.

Ryder, CL, Highwood, EJ, Lai, TM, Sodemann, H \& Marsham, JH 2013a, 'Impact of atmospheric transport on the evolution of microphysical and optical properties of Saharan dust', Geophysical Research Letters, vol. 40, no. 10, pp. 2433-2438. Ryder, CL, Highwood, EJ, Rosenberg, PD, Trembath, J, Brooke, JK, Bart, M, Dean, A, Crosier, J, Dorsey, J, Brindley, H, Banks, J, Marsham, JH, McQuaid, JB, Sodemann, H \& Washington, R 2013b, 'Optical properties of Saharan dust aerosol and contribution from the coarse mode as measured during the Fennec 2011 aircraft campaign', Atmospheric Chemistry and Physics, vol. 13, Copernicus GmbH, no. 1, pp. 303-325.

Ryder, CL, McQuaid, JB, Flamant, C, Rosenberg, PD, Washington, R, Brindley, HE, Highwood, EJ, Marsham, JH, Parker, DJ, Todd, MC, Banks, JR, Brooke, JK, Engelstaedter, S, Estelles, V, Formenti, P, Garcia-Carreras, L, Kocha, C, Marenco, F, Sodemann, H, Allen, CJT, Bourdon, A, Bart, M, Cavazos-Guerra, C, Chevaillier, S, Crosier, J, Darbyshire, E, Dean, AR, Dorsey, JR, Kent, J, O’Sullivan, D, Schepanski, K, Szpek, K, Trembath, J \& Woolley, A 2015, 'Advances in understanding mineral dust and boundary layer processes over the Sahara from Fennec aircraft observations', Atmospheric Chemistry and Physics, vol. 15, Copernicus GmbH, no. 14, pp. 8479-8520.

Seemann, SW, Borbas, EE, Knuteson, RO, Stephenson, GR, Huang, H-L, Seemann, SW, Borbas, EE, Knuteson, RO, Stephenson, GR \& Huang, H-L 2008, 'Development of a Global Infrared Land Surface Emissivity Database for Application to Clear Sky Sounding Retrievals from Multispectral Satellite Radiance Measurements', Journal of Applied Meteorology and Climatology, vol. 47, no. 1, pp. 108-123.

Sunnu, A, Afeti, G \& Resch, F 2008, 'A long-term experimental study of the Saharan dust presence in West Africa', Atmospheric Research, vol. 87, no. 1, pp. 13-26.

Takashima, T \& Masuda, K 1987, 'Emissivities of quartz and Sahara dust powders in the infrared region (7-17 $\mu$ )', Remote Sensing of Environment, vol. 23, Elsevier, no. 1, pp. 51-63.

Tanré, D, Haywood, J, Pelon, J, Léon, JF, Chatenet, B, Formenti, P, Francis, P, Goloub, P, Highwood, EJ \& Myhre, G 2003, 'Measurement and modeling of the Saharan dust radiative impact: Overview of the Saharan Dust Experiment (SHADE)', Journal of Geophysical Research, vol. 108, no. D18, p. 8574.

Walck, C 2007, Handbook on statistical distributions for experimentalists, GEN, University of Stockholm Internal Report SUF-PFY/96-01, available from www. physto. se/ walck.

Xu, J, Hou, S, Qin, D, Kaspari, S, Mayewski, PA, Petit, JR, Delmonte, B, Kang, S, Ren, J, Chappellaz, J \& Hong, S 2010, 'A 108.83-m ice-core record of atmospheric dust deposition at Mt. Qomolangma (Everest), Central Himalaya', Quaternary Research, vol. 73, no. 1, pp. 33-38. 
Atmos. Meas. Tech. Discuss., doi:10.5194/amt-2016-224, 2016

Manuscript under review for journal Atmos. Meas. Tech.

Published: 2 September 2016

(c) Author(s) 2016. CC-BY 3.0 License.
Atmospheric Measurement Techniques

Discussions (c) (1)

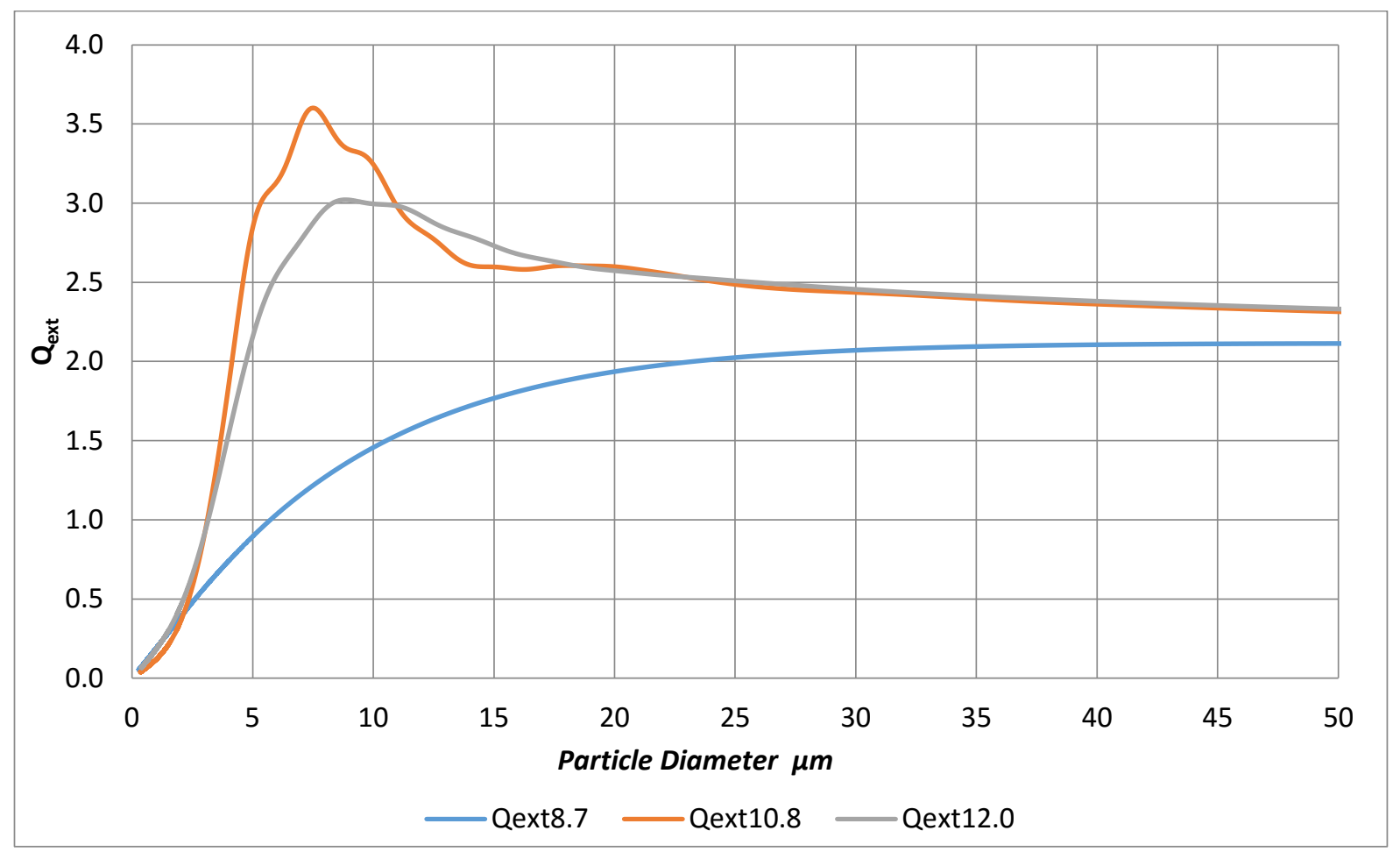

Figure 1: Extinction Efficiency Factor $Q_{\text {ext }}$ at 8.7, 10.8 and 12.0 $\mu \mathrm{m}$ wavelengths versus the particle diameter.

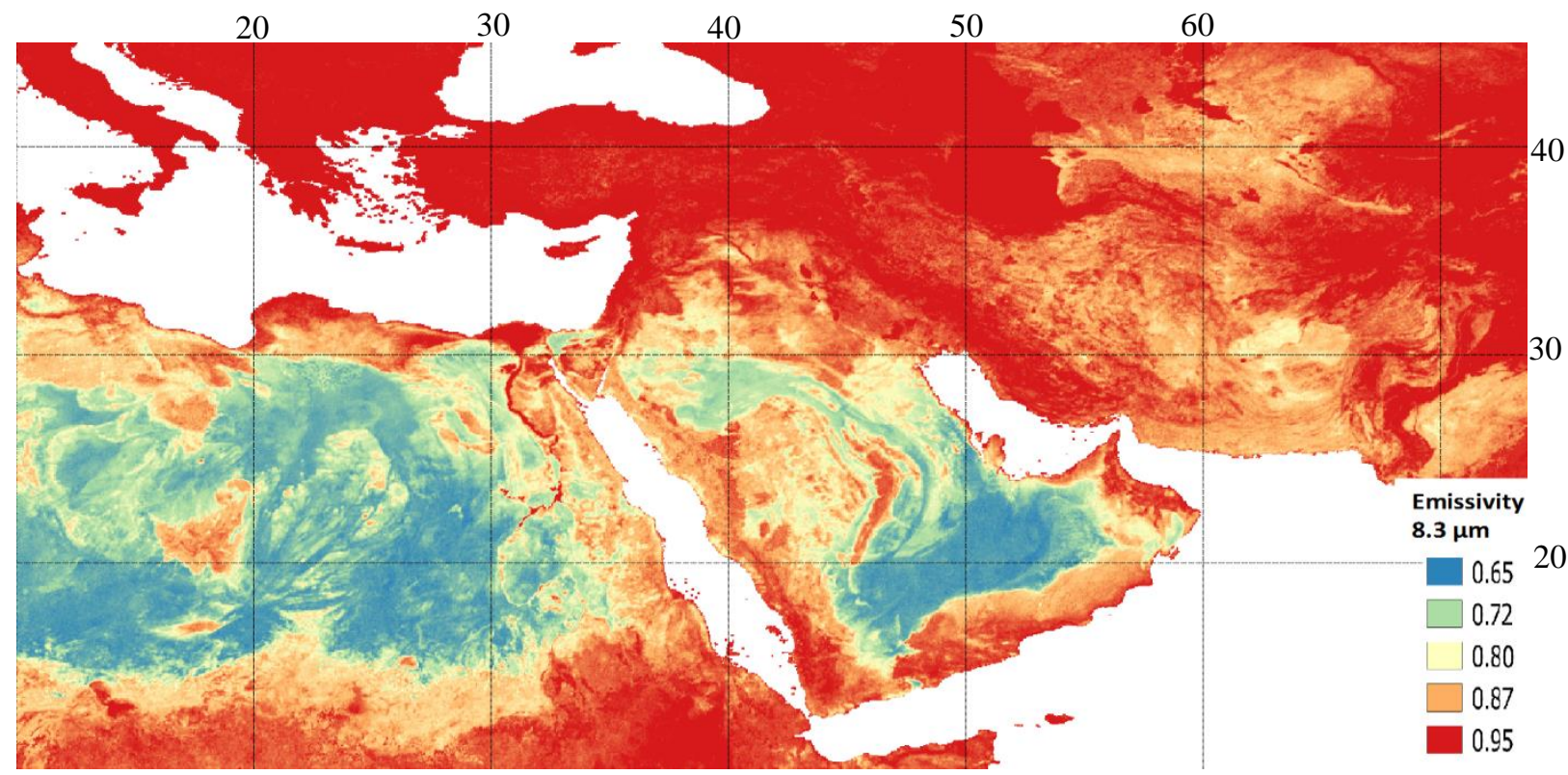

Figure 2: Emissivity at $8.3 \mu \mathrm{m}$, processed using Global Infrared Land Surface Emissivity Database. The image shows strong variability compared to $12.1 \mu \mathrm{m}$ emissivity in Figure 3 
Atmos. Meas. Tech. Discuss., doi:10.5194/amt-2016-224, 2016

Manuscript under review for journal Atmos. Meas. Tech.

Published: 2 September 2016

(c) Author(s) 2016. CC-BY 3.0 License.

\section{Atmospheric \\ Measurement \\ Techniques \\ Discussions}

cc) (P)

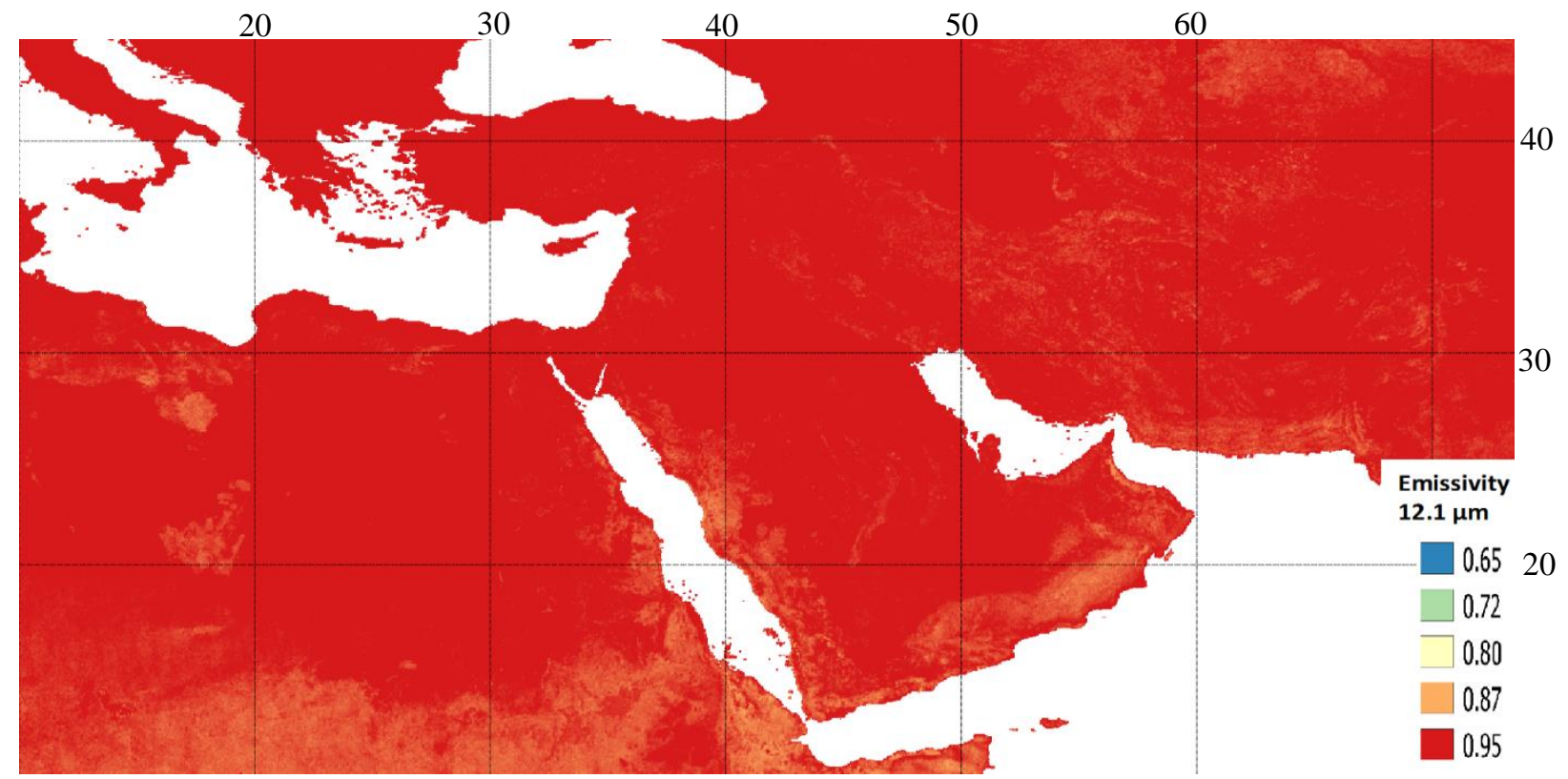

Figure 3: Emissivity at $\mathbf{1 2 . 1} \boldsymbol{\mu \mathrm { m }}$, processed using Global Infrared Land Surface Emissivity Database. The image shows homogeneity compared to $8.3 \mu \mathrm{m}$ (Figure 2 ) around the relatively high value of 0.93 .

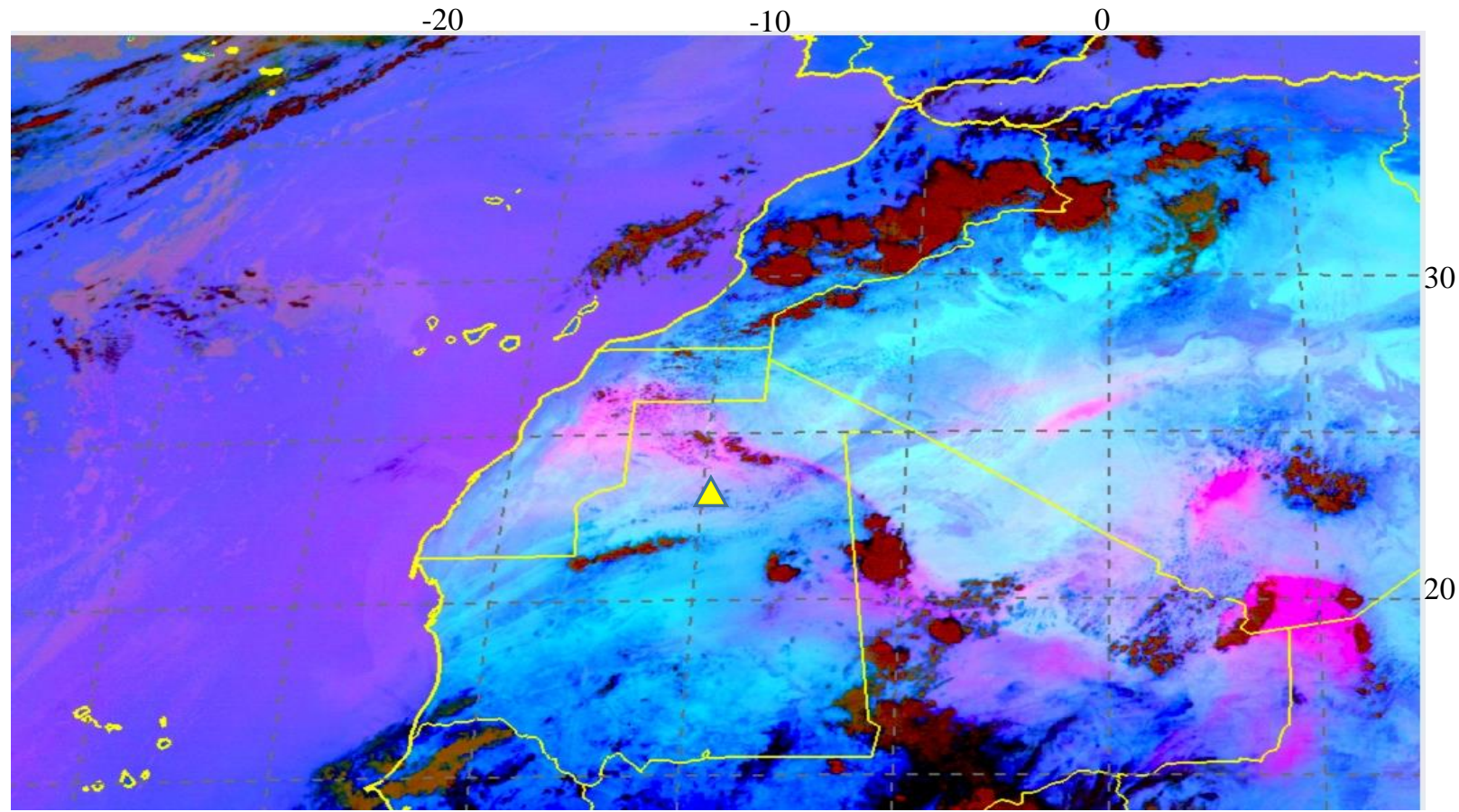

Figure 4: SEVIRI Dust RGB on $20^{\text {th }}$ of June 2011 at 15:30 UTC, the yellow triangle shows the location of Figure 5 (24.0N, 10.0W). 
Atmos. Meas. Tech. Discuss., doi:10.5194/amt-2016-224, 2016

Manuscript under review for journal Atmos. Meas. Tech.

Published: 2 September 2016

(c) Author(s) 2016. CC-BY 3.0 License.

\section{(c) (1)}

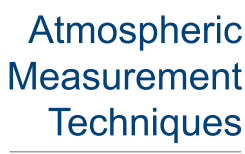

Discussions

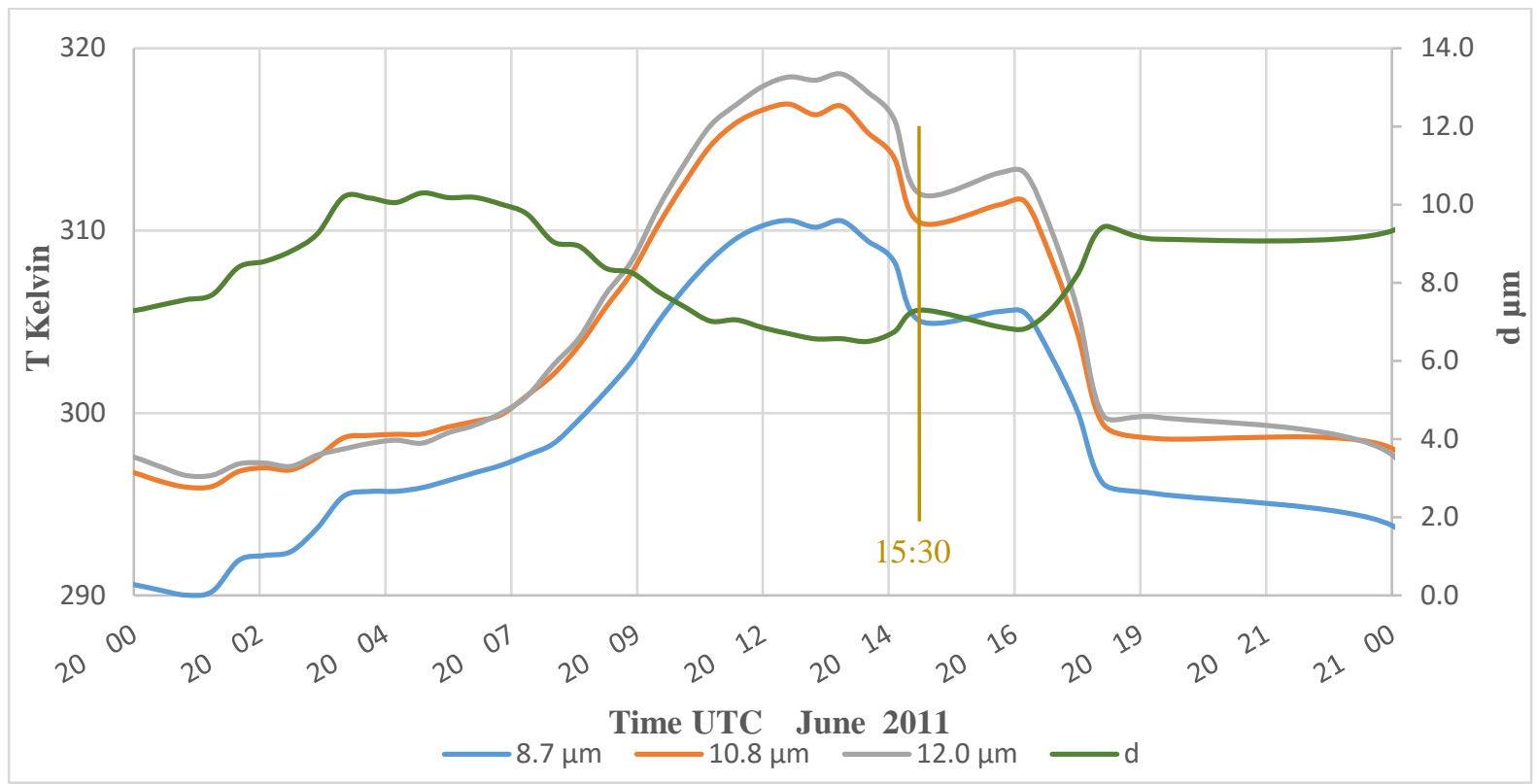

Figure 5: the brightness temperature of 8.7,10.8, 12.0 $\mu \mathrm{m}$ bands (left-hand side vertical axis) and effective diameter $\mathrm{d}$ (right-hand side vertical axis) versus time of the $20^{\text {th }}$ of June 2011 at $24.0 \mathrm{~N}, 10.0 \mathrm{~W}$. The time of the satellite image in Figure 4 is shown.

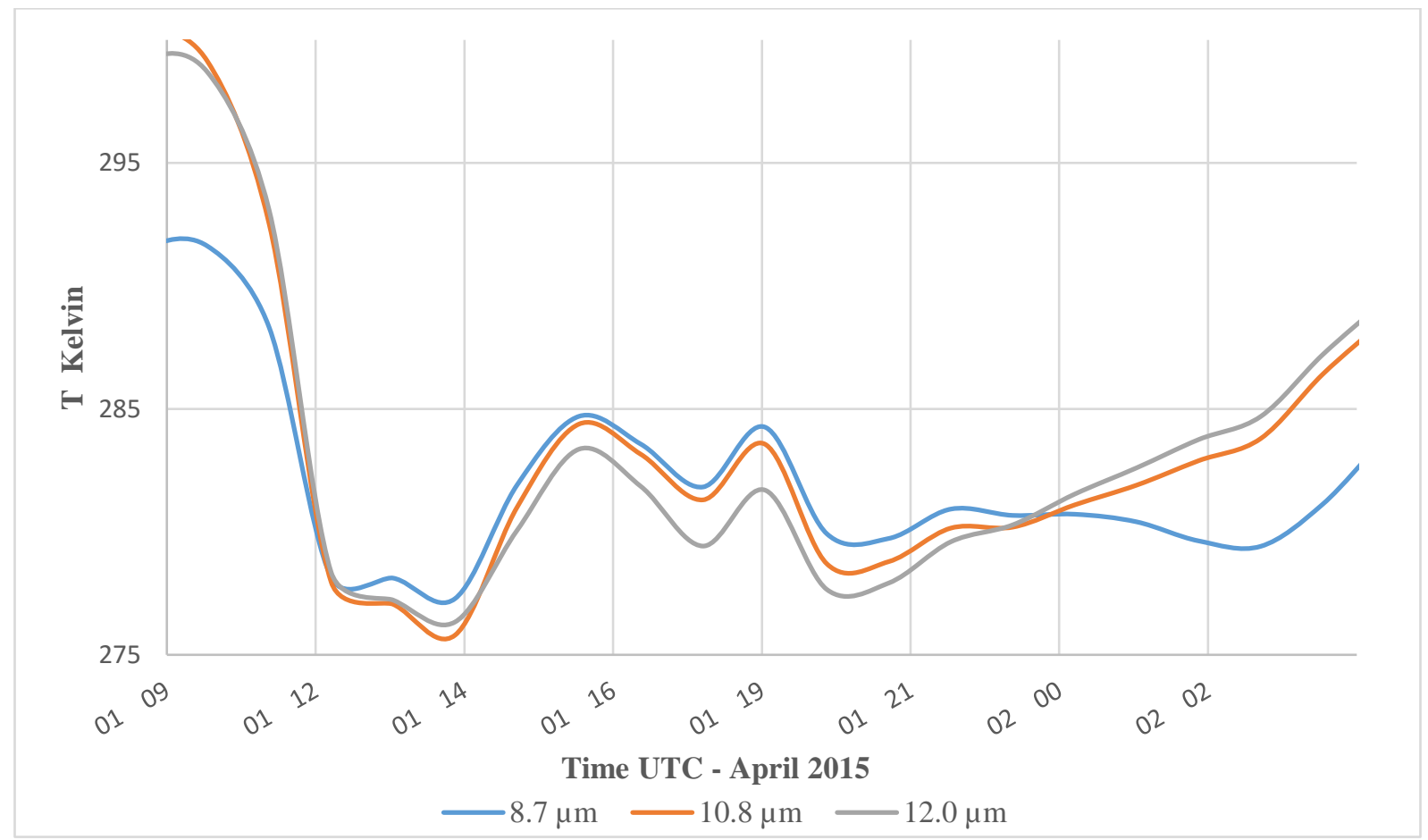

Figure 6: The change of the brightness Temperature (T) of 8.7, 10.8, 12.0 $\mu \mathrm{m}$ SEVIRI bands versus time of the $1^{\text {st }} \&$ $2^{\text {nd }}$ of April 2015 at the location $(27.0 \mathrm{~N}, 47.8 \mathrm{E}$ ) which is affected by a dust cloud (Figure 14). 
Atmos. Meas. Tech. Discuss., doi:10.5194/amt-2016-224, 2016

Manuscript under review for journal Atmos. Meas. Tech.

Published: 2 September 2016

(c) Author(s) 2016. CC-BY 3.0 License.

(c) (i)

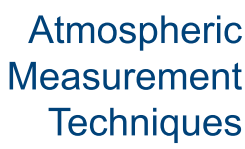

Discussions

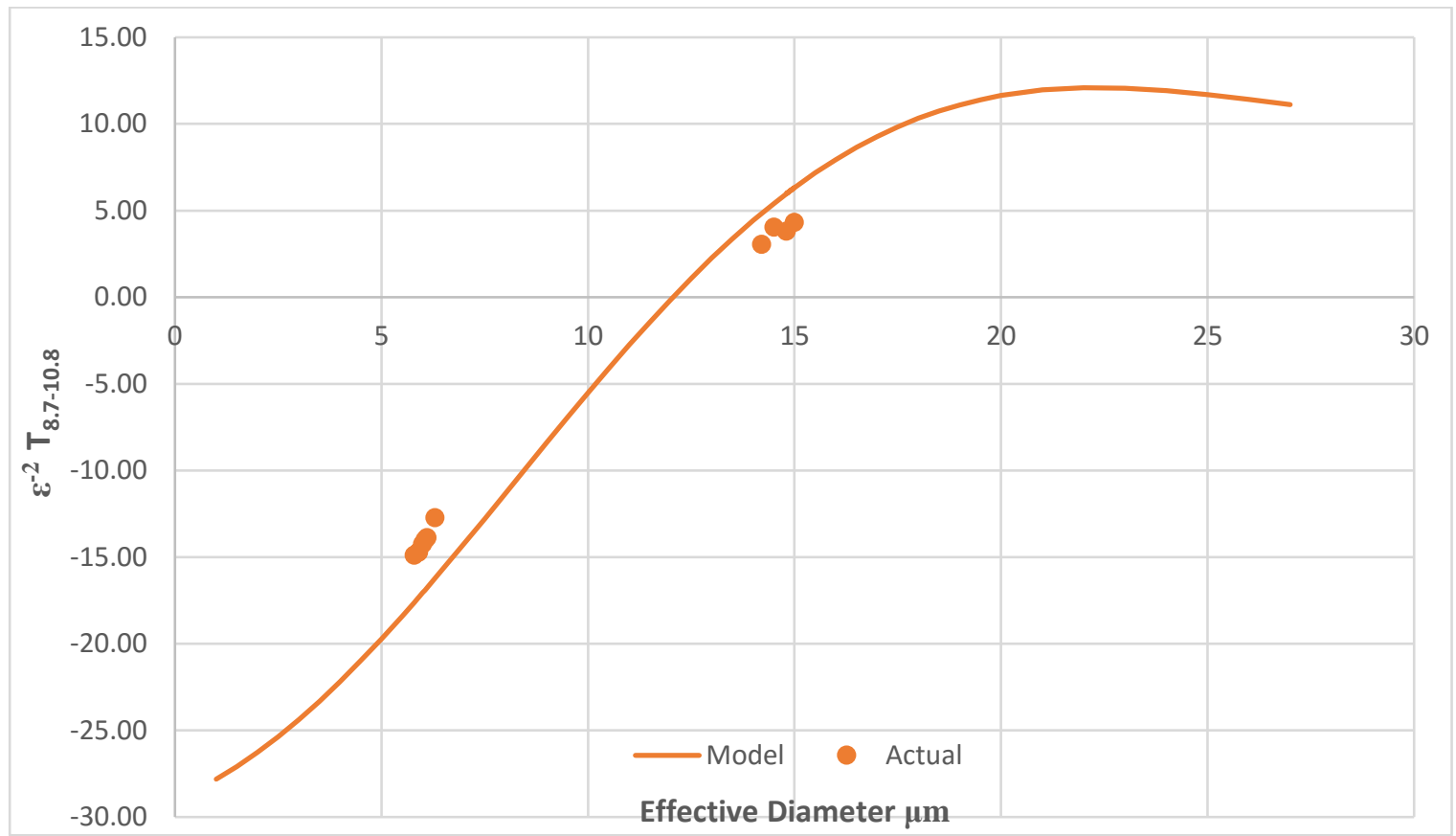

Figure 7: A plot of the model of $\frac{T_{8.7-12.0}}{\epsilon_{8.7}^{2}}$ versus effective diameter $\boldsymbol{d}$ with the actual points used to calculate the coefficients $a, b, c$ and $f$ numerically.

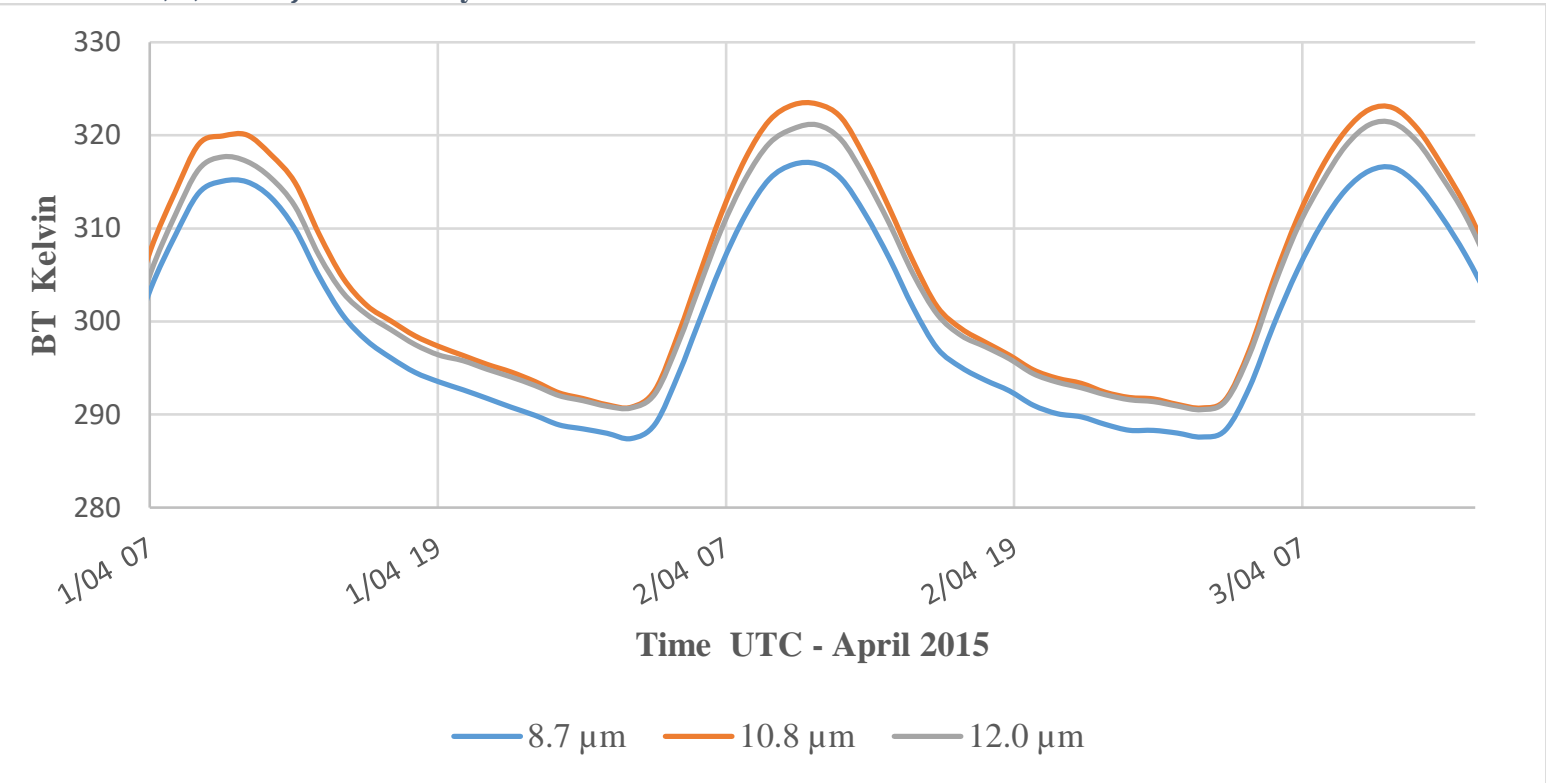

Figure 8: Diurnal change of brightness temperature for a clear sky taken for a point over the desert (16.7N, 34.4E) on 1-3 April 2015. 
Atmos. Meas. Tech. Discuss., doi:10.5194/amt-2016-224, 2016

Atmospheric

Manuscript under review for journal Atmos. Meas. Tech.

Published: 2 September 2016

(c) Author(s) 2016. CC-BY 3.0 License.

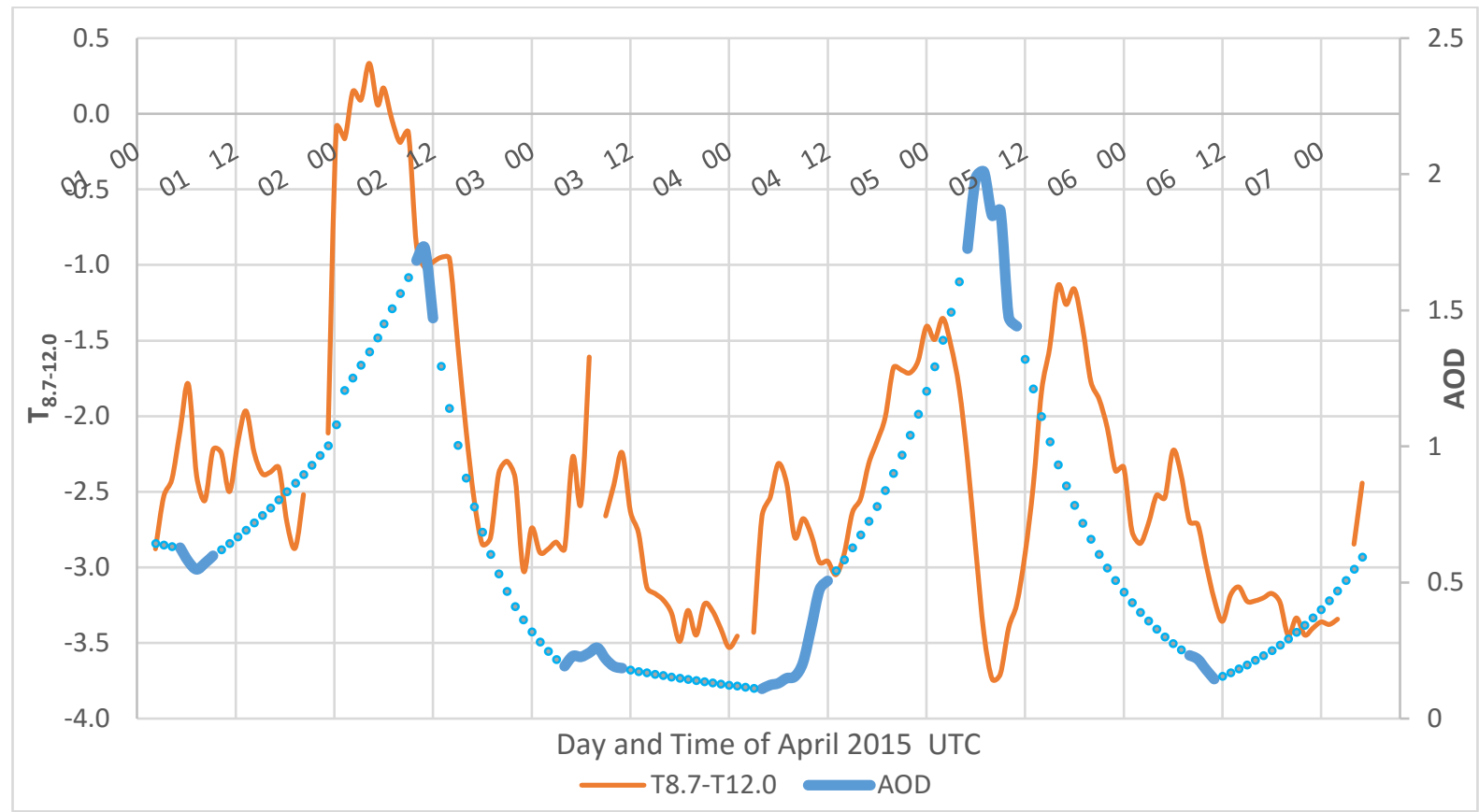

Figure 9: Temperature difference of 8.7 and $12.0 \mu \mathrm{m}$ (left-hand side vertical axis) and AERONET AOD (right-hand side vertical axis) versus time for six days between the $1^{\text {st }}$ to $7^{\text {th }}$ of April 2015 over the city of Abu Dhabi (UAE). The dotted line is an interpolation of the actual observation during the daylight. Limited correlation is observed between the two curves. SEVIRI Dust RGB animation shows that the first peak corresponds to relatively freshly emitted dust while the second corresponds to long transported dust with lower effective diameter expected.

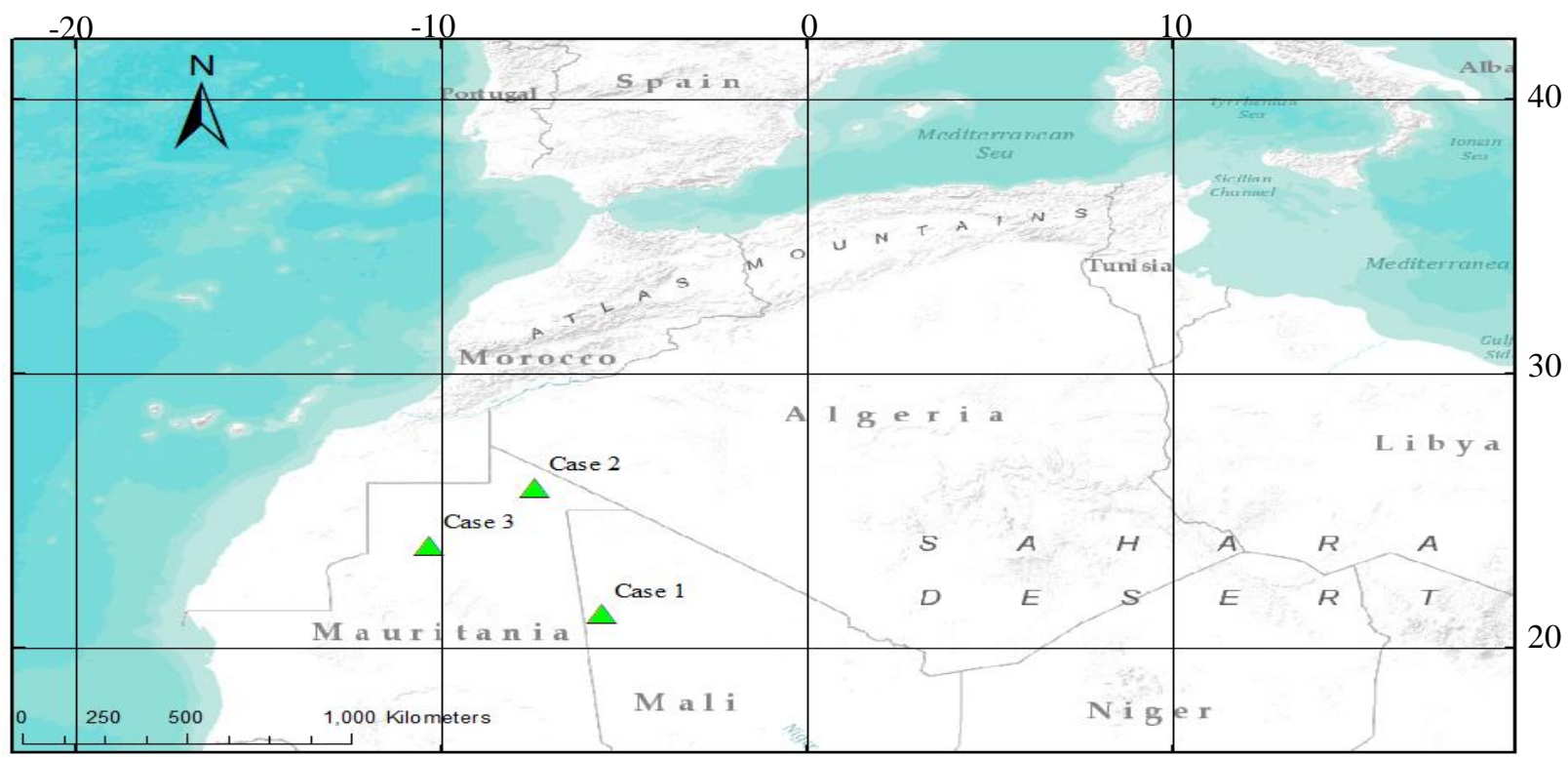

Figure 10: Map of the locations (green triangles) of the three test cases (USGS, NOAA base map 2016). 
Atmos. Meas. Tech. Discuss., doi:10.5194/amt-2016-224, 2016

Atmospheric

Manuscript under review for journal Atmos. Meas. Tech.

Published: 2 September 2016

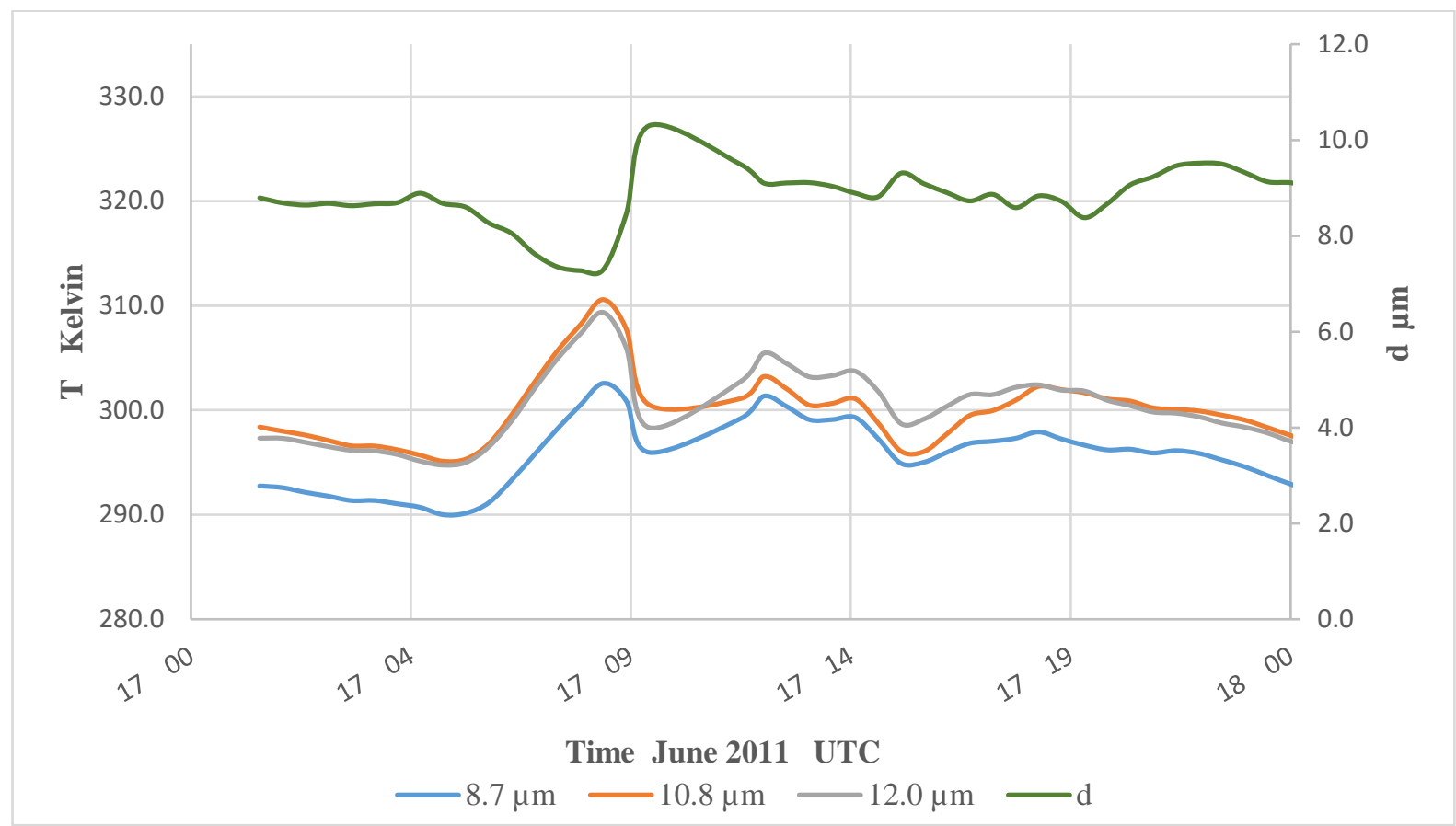

Figure 11: The brightness temperature of 8.7,10.8, 12.0 $\mu \mathrm{m}$ bands (left-hand vertical axis) and diameter $d$ (right-hand vertical axis) versus time of the $17^{\text {th }}$ to $18^{\text {th }}$ of June 2011 at $21.2 \mathrm{~N}, 5.6 \mathrm{~W}$.

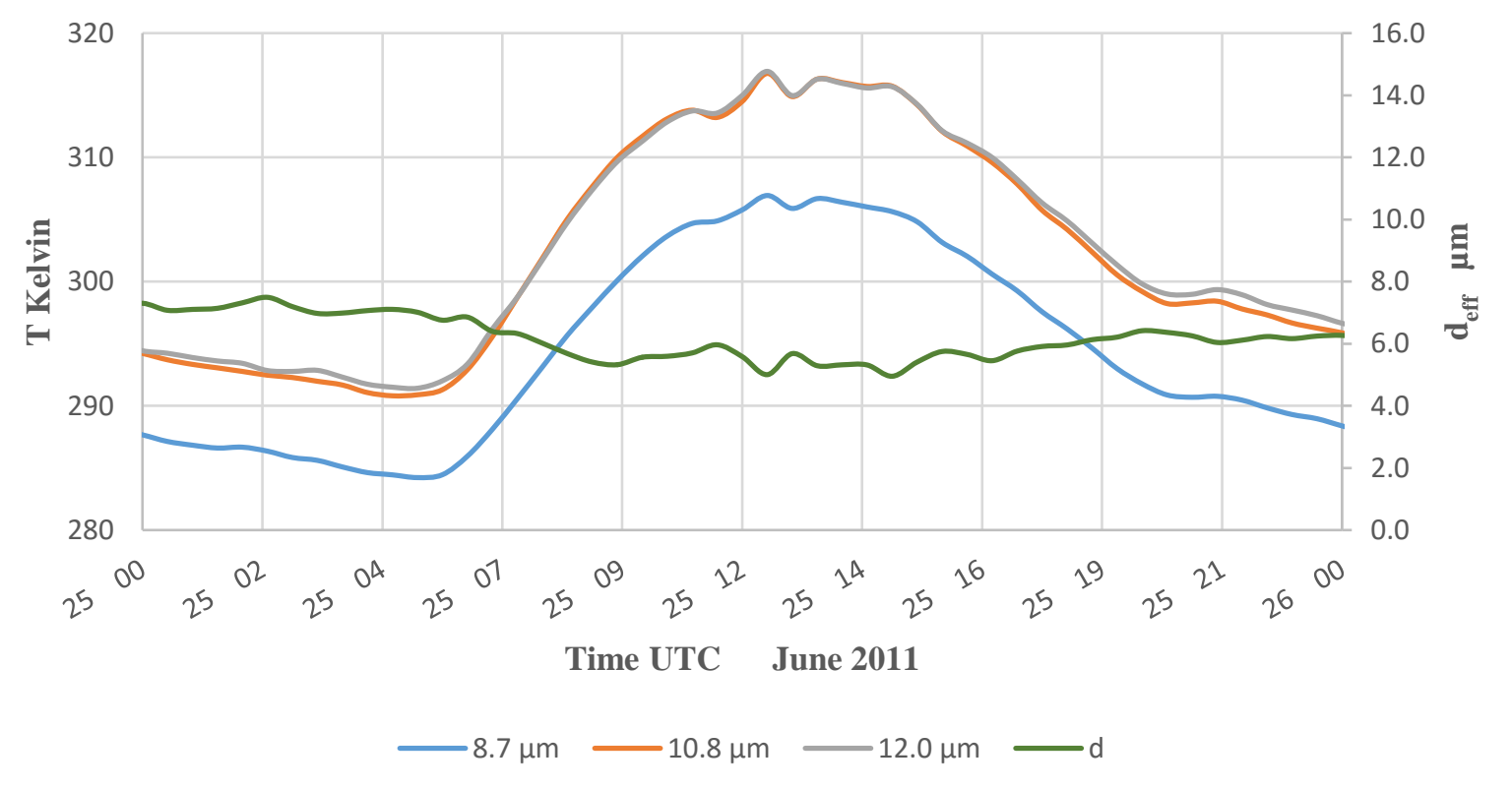

Figure 12: the brightness temperature of $8.7,10.8,12.0 \mu \mathrm{m}$ bands (left-hand vertical axis) and diameter $d$ (right-hand vertical axis) versus time of the $25^{\text {th }}$ of June 2011 at $25.8 \mathrm{~N}, 7.4 \mathrm{~W}$. 
Atmos. Meas. Tech. Discuss., doi:10.5194/amt-2016-224, 2016

Manuscript under review for journal Atmos. Meas. Tech.

Published: 2 September 2016

(c) Author(s) 2016. CC-BY 3.0 License.

(c) (i)

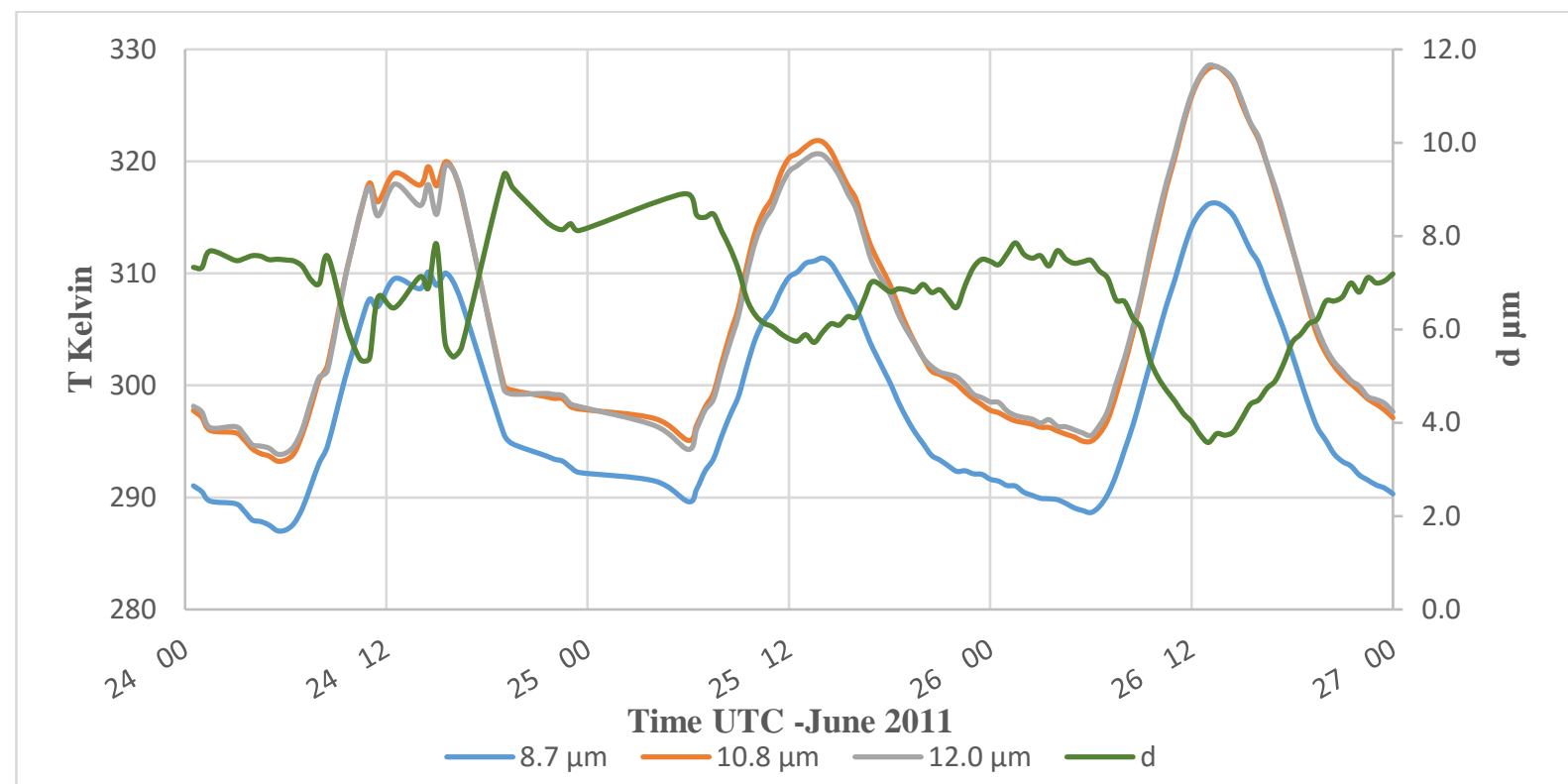

Figure 13: the brightness temperature of $8.7,10.8,12.0 \mu \mathrm{m}$ bands (left-hand side vertical axis) and diameter $d$ (righthand side vertical axis) versus time of the $25^{\text {th }}$ of June 2011 at $23.7 \mathrm{~N}, 10.3 \mathrm{~W}$.

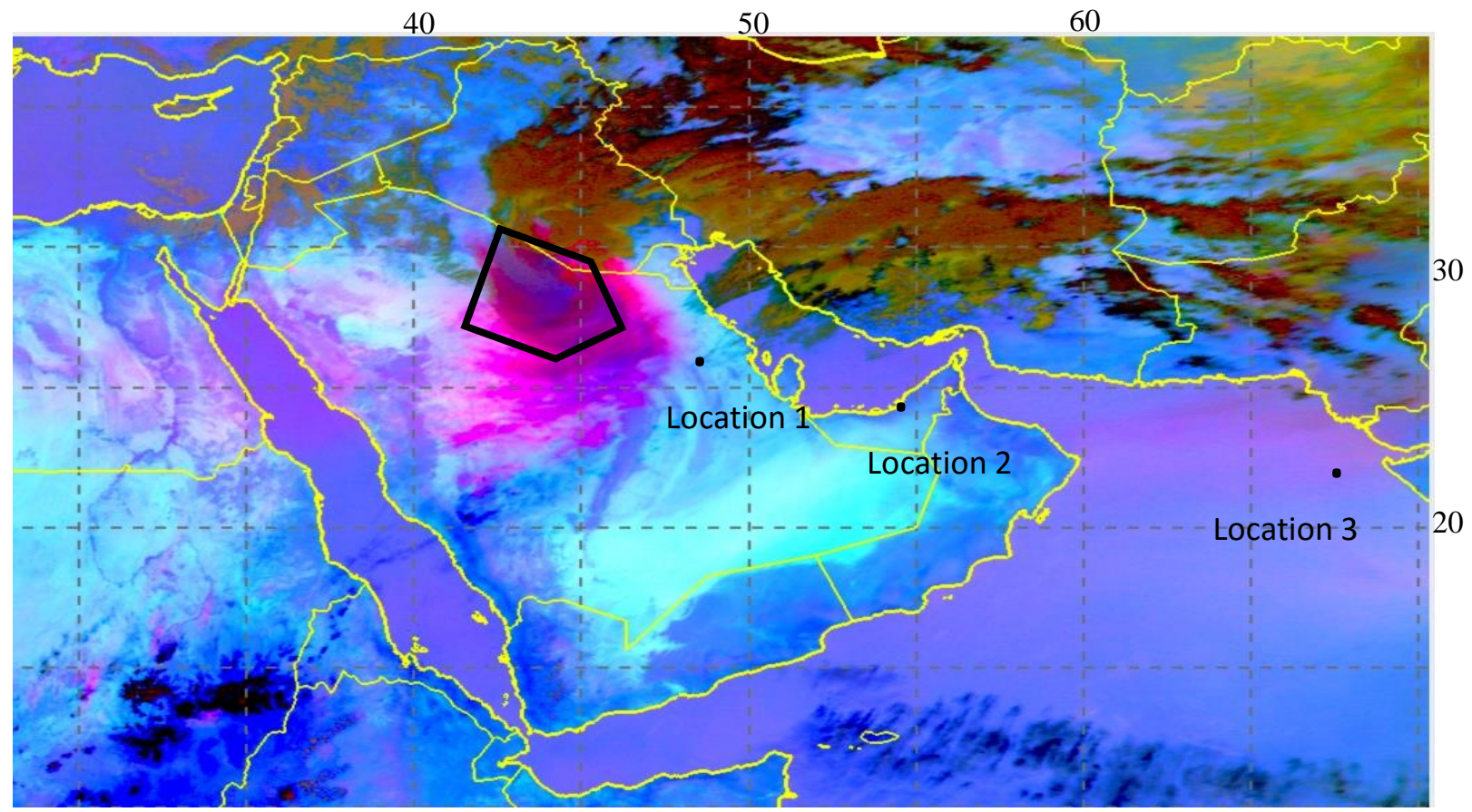

Figure 14: SEVIRI dust RGB for 01.04.2015 11:15 UTC, showing the location where the brightness temperature of 8.7, 10.8, $12 \mu \mathrm{m}$ bands were plotted (Figure 12). The black arrow indicates the direction of the dust storm movement. 
Atmos. Meas. Tech. Discuss., doi:10.5194/amt-2016-224, 2016

Manuscript under review for journal Atmos. Meas. Tech.

Published: 2 September 2016

(c) Author(s) 2016. CC-BY 3.0 License.

(c) (1)

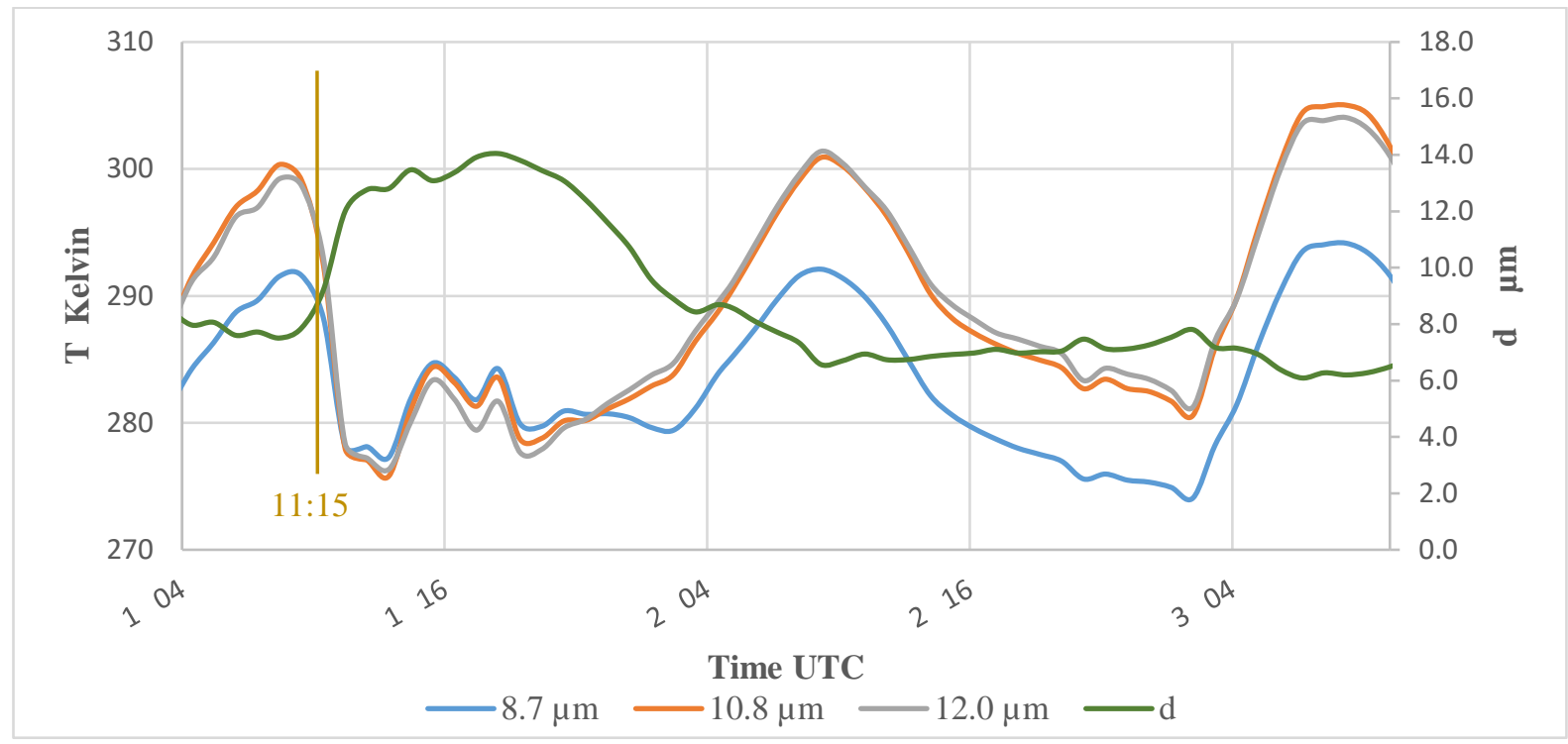

Figure 15: $T$ of 8.7,10.8,12.0 $\mu \mathrm{m}$ bands (left-hand side vertical axis) and $d$ (right-hand side vertical axis) versus time of the $1^{\text {st }} \& 2^{\text {nd }}$ of April 2015 at location\#1(27.0 $\mathrm{N}$ and 47.8 E) which is approximately $300 \mathrm{~km}$ from the centre of the dust emission source, ahead of the dust cloud movement. The time of the satellite image in Figure 14 is shown.

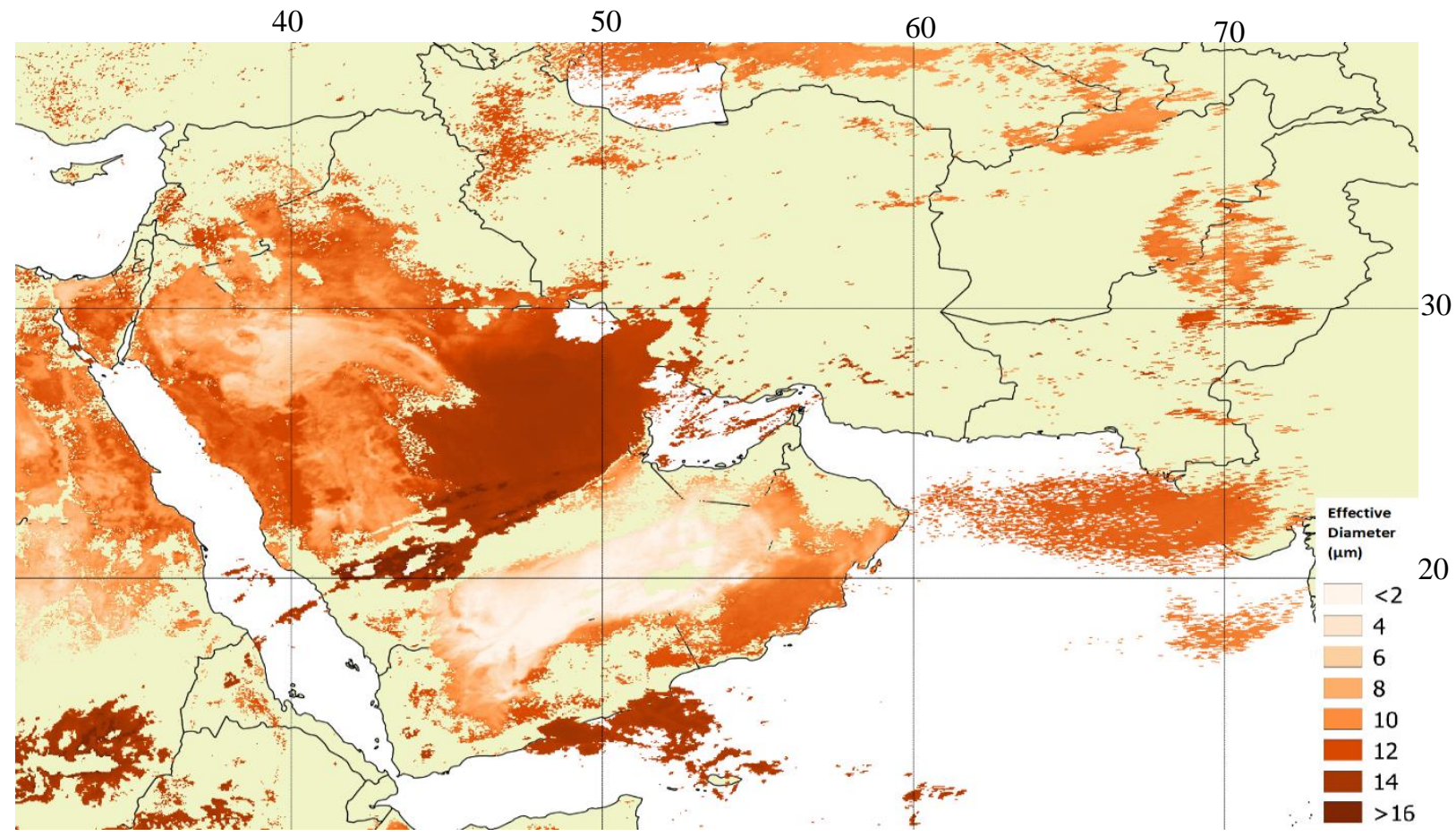

Figure 16: A $4 \mathrm{~km}$ resolution raster shows effective diameter on the $1^{\text {st }}$ April 2015 18:15 UTC calculated using the algorithm. Most of the clouds were screened out. However, few water clouds are still evident in this product (e.g., South East coast of Yemen). 
Atmos. Meas. Tech. Discuss., doi:10.5194/amt-2016-224, 2016

Manuscript under review for journal Atmos. Meas. Tech.

Published: 2 September 2016

(c) Author(s) 2016. CC-BY 3.0 License.

\section{Atmospheric Measurement Techniques \\ Discussions}

(c) (P)

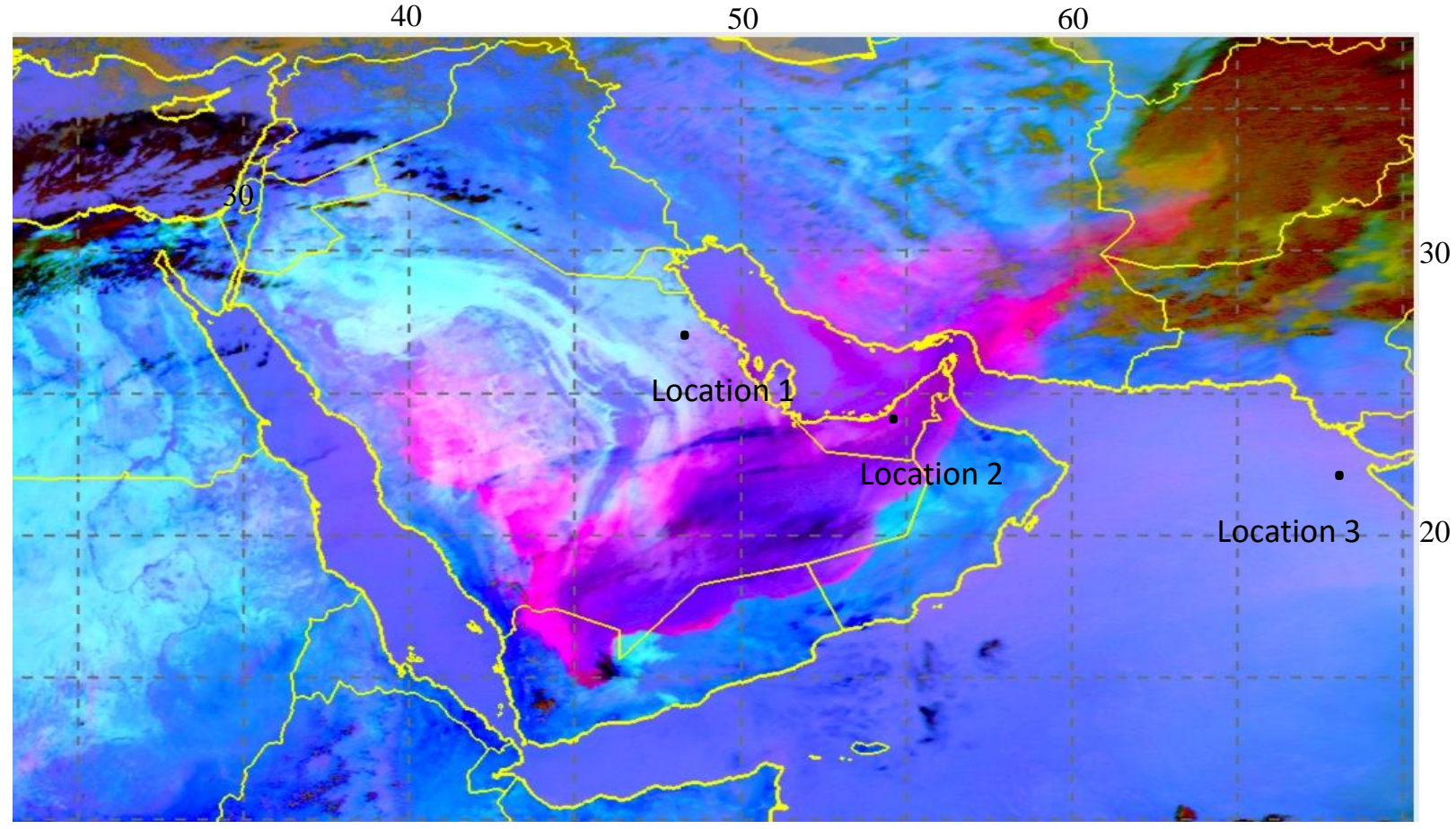

Figure 17: SEVIRI dust RGB for 02.04.2015 11:00 UTC. The dust cloud is over Location\#2.

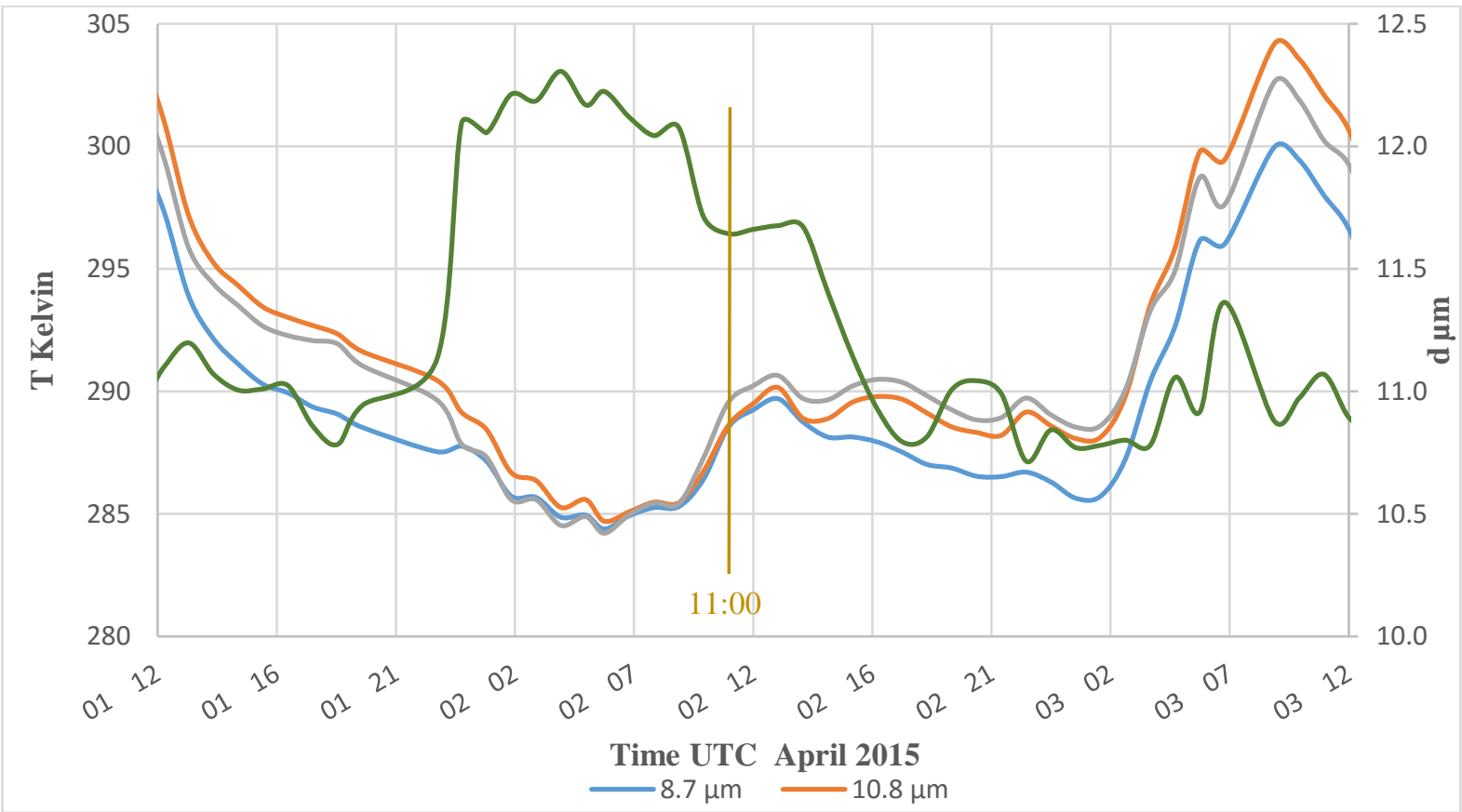

Figure 18: $T$ of 8.7,10.8, $12.0 \mu \mathrm{m}$ bands (left-hand side vertical axis) and $d$ (right-hand side vertical axis) versus time of the $1^{\text {st }}$ to $3^{\text {rd }}$ of April 2015 over Location\#2 (Abu Dhabi). The time of the satellite image in Figure 17 is shown. 
Atmos. Meas. Tech. Discuss., doi:10.5194/amt-2016-224, 2016

Manuscript under review for journal Atmos. Meas. Tech.

Published: 2 September 2016

(c) Author(s) 2016. CC-BY 3.0 License.
Atmospheric Measurement Techniques

Discussions

(c) (1)

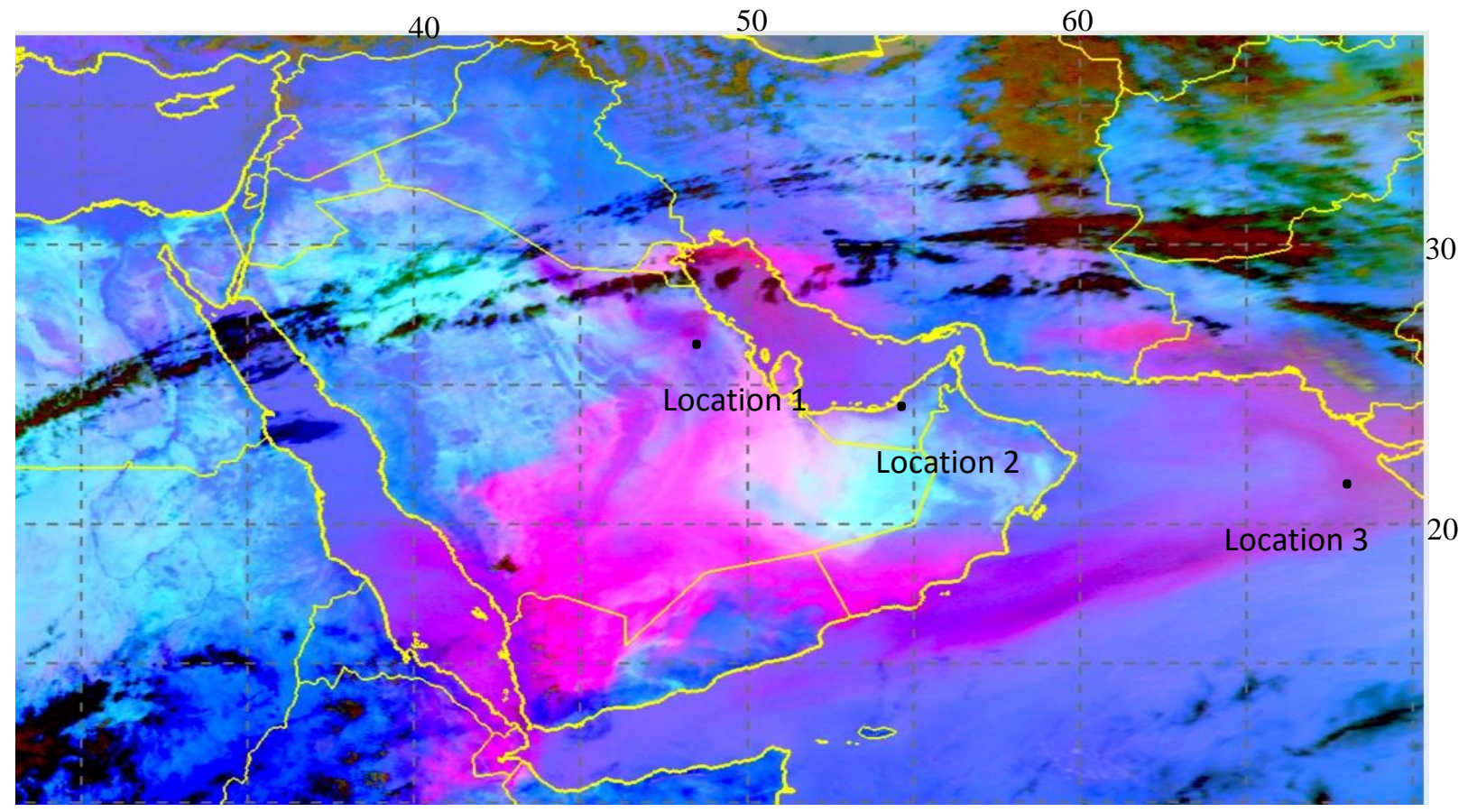

Figure 19: SEVIRI dust RGB for 04.04.2015 12:00 UTC. The dust cloud is over Location\#3.

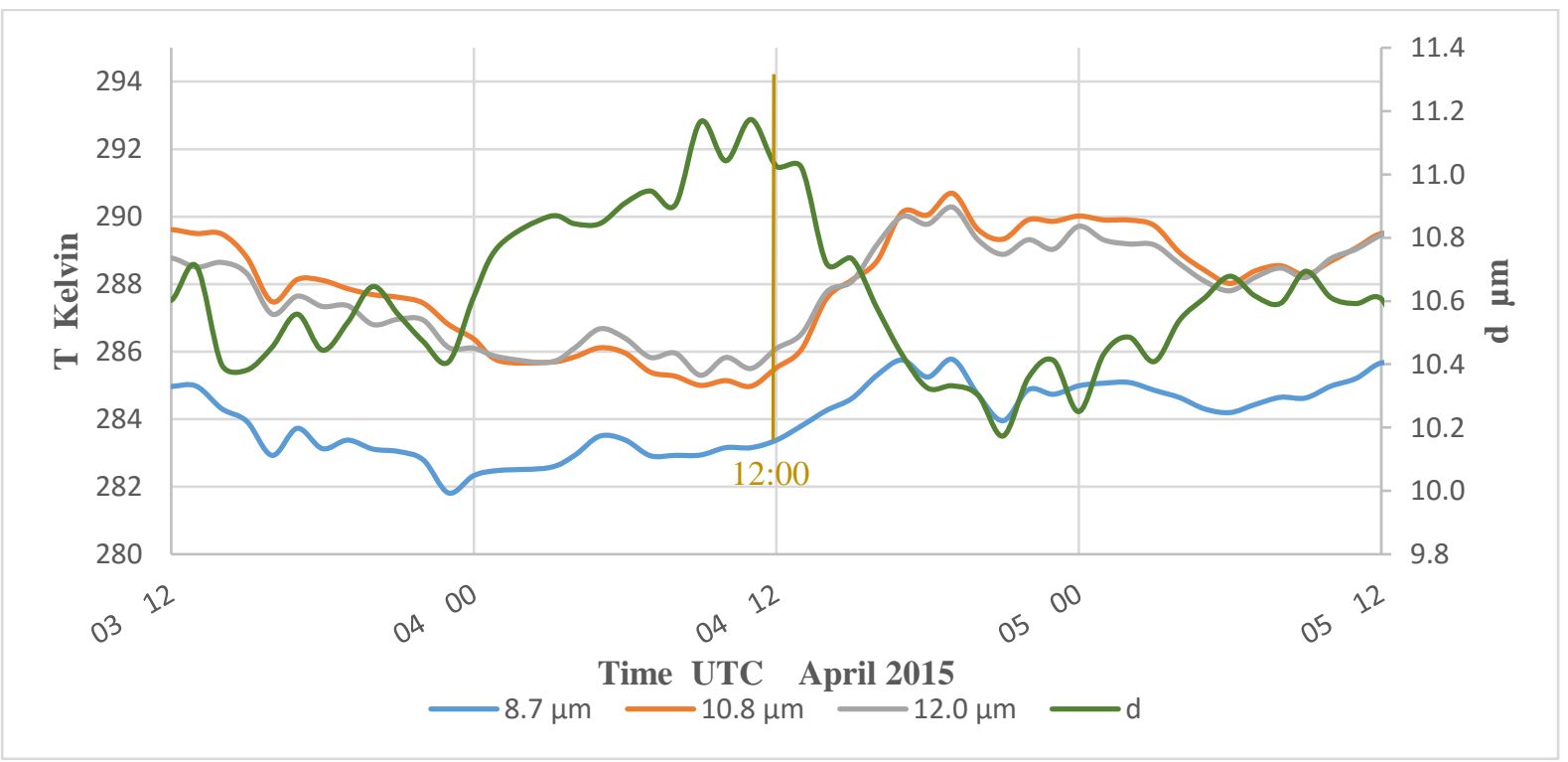

Figure 20: $T$ of 8.7,10.8, 12.0 bands (left-hand side vertical axis) and $d$ (right-hand side vertical axis) versus time of the $3^{\text {rd }}$ to $5^{\text {rd }}$ of April 2015 over Location\# 3 (21.9N, 67.9E). The time of the satellite image in Figure 19 is shown. 
Atmos. Meas. Tech. Discuss., doi:10.5194/amt-2016-224, 2016

Atmospheric

Manuscript under review for journal Atmos. Meas. Tech.

Published: 2 September 2016

(c) Author(s) 2016. CC-BY 3.0 License.

\begin{tabular}{|l|l|l|l|l|}
\hline $\begin{array}{l}\text { Case } \\
\text { Number }\end{array}$ & Location & $\begin{array}{l}\text { Sampled } \\
(\mu \mathrm{m})\end{array}$ & $\begin{array}{l}\text { Modelled } \\
(\mu \mathrm{m})\end{array}$ & $\begin{array}{l}\text { 95\% confidence interval } \\
\text { for a single value }(\mu \mathrm{m})\end{array}$ \\
\hline Case \#1 & Mali; 17-18 June 2011 "Recent uplift" & 12.3 & $9.6 \pm 0.7$ & 8.8 to 11.4 \\
\hline Case \#2 & Mauritania; 25 June 2011 "Recent uplift" & 8.6 & $6.2 \pm 1.2$ & 5.1 to 10.0 \\
\hline Case \#3 & Mauritania; 24-26 June 2011 “Long transported" & 5.9 & $6.0 \pm 1.3$ & 3.1 to 8.4 \\
\hline
\end{tabular}

Table 1: Summary of the model testing results with one standard deviation and $95 \%$ confidence interval from a single value. 